\title{
Synopsis of the species of Myxobolus (Cnidaria, Myxozoa, Myxosporea) described between 2014 and 2020
}

\author{
Jorge C. Eiras ${ }^{1,2}$, Cristina F. Cruz ${ }^{1,2}$, Aurélia Saraiva ${ }^{1,2}$ and Edson A. Adriano ${ }^{3}$ \\ ${ }^{1}$ Departamento de Biologia, Faculdade de Ciências, Universidade do Porto, Porto, Portugal; \\ ${ }^{2}$ CIIMAR - Centro Interdisciplinar de Investigação Marinha e Ambiental, Matosinhos, Portugal; \\ ${ }^{3}$ Departamento de Ecologia e Biologia Evolutiva, Universidade Federal de São Paulo - UNIFESP, Diadema, SP, Brazil
}

\begin{abstract}
A synopsis of the species of Myxobolus Bütschli, 1882 (Cnidaria, Myxosporea, Myxobolidae) described from 2014 up till now is presented. It includes 122 nominal species described all over the world. For each of the species, the most relevant morphological and morphometric data, as well as data are provided related to the location in the host, type host and type locality. The GenBank accession numbers are provided whenever possible, and the spores were redrawn based on the original descriptions. The bibliography includes all the papers containing the species descriptions.
\end{abstract}

Keywords: Endocnidozoa, taxonomy, fish parasite, diversity

The genus Myxobolus Bütschli, 1882 is between the most diversified Cnidaria of the class Myxozoa. They are mainly fish parasites and have a huge number of different host species, both freshwater and marine ones. Besides Myxobolus cerebralis (Hofer, 1903), causing the well-known whirling disease, some other species of Myxobolus have also proved to be pathogenic to their hosts (Camus and Griffin 2010, Kaur et al. 2015). Eiras et al. $(2005,2014)$ published two synopses of Myxobolus, which together attained 856 valid species. These papers proved to be useful for researchers interested in the group as judged by the high number of citations they reached - some 358 according to ResearchGate or 399 according to Google Scholar. Driven by the wide acceptance of this type of synopsis by the scientific community of the area, this paper has as aim to compilate the species of Myxobolus described from 2014 to date. The authors hope the present compilation is a useful tool for the researchers interested in this interesting group of parasites.

\section{MATERIALS AND METHODS}

The present list is based on an extensive internet search, as complete as possible, to detect all the species described since 2014. The authors recognise that, despite their efforts, some species were probably inadvertently overlooked, especially those in papers published in local journals, but hope that such omissions have been kept to a minimum.

The data are organised in tabulated format including the species name, authority, type host and type locality whenever possible, location in the host, description of vegetative stages and spores, including dimensions, and GenBank accession numbers when available.

Spores were re-drawn from the original illustrations, but some were not presented to scale as appeared in the original publications. A complete reference list including all the papers containing the species descriptions is presented. Fish names in Table 1 follow FishBase (Froese and Pauly 2019).

\section{RESULTS}

Our literature search resulted in 122 species of Myxobolus, which are distributed in all continents, except the Antarctic.

The species features, as mentioned in Materials and Methods, are reported in Table 1 and the drawings of the spores are presented in Figs 1-121. The exception is Myxobolus bragantinus Cardim, Silva, Hamoy, Matos et Abrunhosa, 2018, which was not illustrated in the original description.

\section{DISCUSSION}

Eiras et al. $(2005,2014)$ provided previous synopses of species of Myxobolus. Until 2005, there were 744 nominal species, and nine years later 112 species had been added, attaining a total number of 856 nominal species (Eiras et al. 2014). The new synopsis here presented shows the addition of 122 species to the genus Myxobolus, totaling now 979 taxa. It is interesting to note that, compared with the period covered by the last synopsis (Eiras et al. 2014), the present one shows an increase of $65 \%$ in the mean annual 
number of description of new species. In the first synopsis, there was a mean of 12.4 new species/year (112 species/ nine years), while now there is an increase to 20.5 species/ year (122 species/seven years). This increase in the pace of description of species suggests that there is still an undescribed diversity of species of Myxobolus to be revealed, and the success in this task will depend on the amount of researchers involved in this research area.

Concerning the 122 species presented in this synopsis, it is important to note that almost half (47\%) were reported from two country - i.e., India with 35 species and Brazil with 23. This is probably due to two facts: (i) the diversity of fishes is very high in both countries, and (ii) there are several research groups well-established and involved in prospecting myxosporean diversity. Therefore, it cannot be concluded that Myxobolus spp. are more abundant (in relative terms considering the number of fish species within a country) if a similar research effort were done in some other countries with high fish diversity.
Another question relates with the habitat of the host fish species. The great majority of new taxa are from freshwater or, at least, were captured in a freshwater environment. We think that this does not necessarily means that Myxobolus spp. are more abundant in freshwater. The increase in parasitological studies of marine fish shall demonstrate in the future whether this assumption is correct.

Acknowledgements. The authors are grateful to several colleagues who provided some of the species descriptions: A. Chandran, R. Abdel-Gaber, Bing-Wen Xi, H. Sato, Anabela Costa, C. Antunes, S. Ghosh, Kálmán Molnár, T.G. Rosser, D. Vieira, A. Gupta, E. Kato, Stephen Atkinson, Jan Lovy, J.M. Liu, Juliana Naldoni, Istiyaq Ahmad, Naireen Fariya, Paula Marcotegui, Harpreet Kaur, J. Stilwell. Participation of J.C. Eiras, A. Saraiva and C. Cruz in this study was supported by national funds through FCT - Foundation for Science and Technology within the scope of UIDB/04423/2020 and UIDP/04423/2020.

Table 1. Features of Myxobolus spp. described between 2014 and 2020: characteristics of the vegetative stages and spores, type host and type locality, and molecular data when available. Abbreviations: P, vegetative stage; SP, spore; PC, polar capsule; NC, number of coils of the polar filament; IP, intercapsular process; GBAN, Genbank accession number. The dimensions of the spores are indicated as length $\times$ thickness $\times$ width, and of the polar capsules as length $\times$ thickness. All measurements are in micrometres, except those of the vegetative stage that are provided in $\mathrm{mm}$. The host names are those given in the original publications.

$\begin{array}{lll}\text { Species } & \text { Characteristics } & \text { Type host and type locality References }\end{array}$

M. adeli Yurakhno et Ovcharenko, 2014
P spindle-shaped, 0.5-1.3, in intestine, pyloric caeca, oesophagus, stomach, swim bladder, sporadically in gills and muscles; SP oval, transversally widened, $6.1(5.5-6.7) \times 7.2(6.5-7.7) \times 4.6(3.5-5.2)$; PC equal, $3.0(2.3-3.8) \times 1.8(1.2-2.2)$, NC 4. Other localities: Santa Chelon auratus (Risso); Ebro Yurakhno and Pola Bay, Spain, Black Sea waters (Kerch Channel) and Azov Sea River Delta, Spain (Genischesk aquatoria - sic); note: the authors did not indicate a typehost or a type-locality. Fig. 1.

M. adiposus Rocha, Casal, $\mathrm{P}$ in the adipose tissue surrounding the optic nerve in the ocular cavity, Chelon ramada (Risso); Alves, Antunes, Rodrigues
et Azevedo, 2019 3.0 (2.7-3.3), NC 6-7; GBAN: MK 203076. Fig. 2. P ovoidal, creamish white, $0.2-0.9$, in gill filaments; SP pyriform,

$M$ adlardi Gupta et Kaur, ellipsoidal in frontal view, lemon-shaped in sutural view, $7.9(7.8-8.1)$ M. adlardi Gupta et Kaur, 2016 $\times 4.8$ (4.7-4.9); PC bottle-shaped, equal, $3.5(3.4-3.6) \times 1.7(1.6-$ 1.8), NC 6-7. Fig. 3.

M. adrianoi Mathews, Madrid, Martins, Rigoni et Morandini, 2020

In serosa of intestine; SP ellipsoidal, elongated, smooth, up to $22.4 \pm 0.3$ $\times 16.3 \pm 0.1$, in serosa layer of intestine; PC elongated, aubergineshaped, equal, $14.3 \pm 0.2 \times 6.5 \pm 0.1$; NC 5. Fig. 4 .

$P$ white, spherical, polysporic, in intralamellar-vascular locations

M. anatolicus Pekmezci, Yardimci, Yilmaz et Polat, 2014 in gills, 0.2 to 1.4 in diameter; SP equal, oval in frontal and sutural views, tapered at anterior pole, $10.1(9.4-10.7) \times 6.9(6.6-7.2) \times 4.5$ (4.4-4.6), IP not present; PC pyriform, equal, $4.6(4.4-4.8) \times 2.1$ (2-2.3), NC 5-6; GBAN: KF537629. Fig. 5.

$P$ rounded, yellow, in pyloric caecum; SP oval in frontal view,

M. arapiuns Capodifoglio, Meira, Silva, Corrêa, Adriano et Maia, 2020 fusiform and symmetrical in lateral view, wall smooth with sutural folds, $12.9(11.6-3.7) \times 7.5(6.8-8.2) \times 5.4(5.1-5.6)$; PC equal, 5.4 $(4.9-6.0) \times 2.2(1.9-2.4)$, NC 4-5; GBAN: MN239502. Fig. 7.

Labeo rohita (Hamilton) Ranjit Sagar Wetland, Punjab, India

Corydoras schwartzi Rössel; Purus River, near Municipality of Labrea, Amazonas state, Brazil

Capoeta tinca (Heckel); Ondokuzmayis, Samsun Province, Turkey

Piaractus brachypomus (Cuvier); Tapajós River, Municipality of Santarém, Pará state, Brazil

M. arariensis Abrunhosa, Sindeaux-Neto, Santos, Hamoy et Matos, 2018

$\mathrm{P}$ whitish, about 1.37 in diameter, in epaxial and hypaxial muscles; SP Rhamdia quelen (Quoy

P whitish, about 1.37 in diameter, in epaxial and hypaxial muscles; SP et Gaimard); Arari River, 1.9 (1.7-2.2); GBAN: MG572219. Fig. 6 .

$\mathrm{P}$ in hematopoietic tissue of kidneys and undifferentiated tissue of M. arcasii Rocha, Azevedo, gonads; SP subspherical in valvular view and ellipsoidal in sutural Alves, Antunes et Casal, 2019 gonads; SP subspherical in valvular view and ellipsoidal in sutural
view, 6-8 markings near suture line, $9.7(9.3-10.7) \times 8.1(8.0-8.7)$ view, $6-8$ markings near suture line, $9.7(9.3-10.7) \times 8.1(8.0-8.7) \times$
$6.5(6.3-6.7)$; PC pyriform, equal, 3.9 $(3.3-4.3) \times 3.0(2.7-3.3)$, NC 6 (rarely 7); GBAN: MK 053784. Fig. 8.

P elongated, 1.0-1.5, inside afferent artery of central and distal part of gill filaments; SP ellipsoidal or shortly ellipsoidal in frontal view, lemon-shaped in sutural view, sutural extensions present, about. 0.6

M. arrabonensis Cech, at anterior and 1 at posterior pole of spores, $8.7(8.4-10.0) \times 7.8$ 2015 Island, Brazil

Achondrostoma arcasii

(Steindachner); River Minho Rocha et al. (2019a) Portugal

Chondrostoma nasus (Linnaeus); River Danube at Cech et al. (2015) Győr, Hungary

$(7.6-8.0) \times 5.5(5.4-5.6)$; PC pyriform, subequal in size, $4.8(4.5-5)$
$\times 2.9(2.7-3.1)$, NC 6; IP triangular, $1.5(1.3-1.9)$ long; GBAN:

KP025680-KP025683. Fig. 9. 
$P$ in gills (intralamellar vascular type), $0.5-0.4$ in size; SP oblong M. atkinsoni Gupta et Kaur, to oval shaped in valvular view, elliptical in sutural view, anterior $\begin{array}{ll}\text { M. atkinsoni Gupta et Kaur, end truncated, 6-7 parietal markings on posterior margin, } 7.4 \times 6.8 \text {, } \\ 2018 & \text { without IP; PC oval and unequal, the larger } 2.9 \times 2.4 \text {, NC } 6-7 \text {, the }\end{array}$ smaller $2.0 \times 1.7$, NC 5-6; GBAN: KX143867. Fig. 10

$P$ white in gill filaments, $0.28-0.39$; SP oval to ellipsoidal in valvular M. awadhii Fariya, Abidi et view, lenticular in sutural view, $10.5(7.7-11.6) \times 6.7(5.7-7.3) \times 4.8$ Chauhan, $2018 \quad(4.4-5.1) ;$ PC pyriform, tapered anteriorly, equal, $4.6(3.7-5.8) \times 1.6$ $(1.1-2.1)$, NC 5-7. Fig. 11.

$\mathrm{P} 0.8-0.9$ in the third ventricle of brain and $0.1-0.15$ in inner plexiform layer of retina; SP elongate, tear drop, curved and pointed M. axelrodi Camus, Dill, anteriorly, rounded posteriorly, $20.5(19.0-21.8) \times 6.6(5.7-7.9) \times 5$. Rosser, Pote et Griffin, 2017 (4.8-5.9); PC unequal, the larger 9.9 (8.0-11.2) × 3.8 (3.2-4.8), NC about 15-17, the smaller (stunted) $4.1(3.5-4.5) \times 2.0(1.8-2.3)$, NC about 5-6. Fig. 12.

P ellipsoidal, $0.6-0.8 \times 0.4-0.4$ in gill filaments; SP ellipsoidal in frontal view and lemon-shaped in sutural view, sutural protrusion $\begin{array}{ll}\text { M. balatonicus Székely, } & \text { forming a circular rim around spore, emerging about } 0.6 \text { to } 1.1 \text { over } \\ \text { Molnár et Cech, } 2015 & \text { spore surface, } 7 \text { distinct sutural edge marks, 10.1-12.2 }\end{array}$

7.1-7.8; PC equal, slightly converging anteriorly, $4.9-6 \times 3-3.7, \mathrm{NC}$ 6; IP large, cuneiform; GBAN: KP205545. Fig. 13.

$\mathrm{P}$ large, disporoblastic, roundish, $2-3 \times 0.2-04$, inside multilayered epithelium of gill filaments; SP ovoidal, bluntly pointed with a smal

M. basuhaldari Székely, Cech, Chaudhary, Borzák, Singh et Molnár, 2015 knob at tapered anterior end, $7.3(6.8-7.8) \times 5.5(5.1-6.2) \times 3.7$ (3.5-3.8); PC equal, pear shaped, 3.2 (2.9-3.7) × 2.1 (2.0-2.2), NC 5; additional host: Catla catla, same locality; GBAN: KM029974 for holotype, and KM 029975 and KM 029976 for paratypes. Fig. 14. $\mathrm{P}$ whitish, round, about 2.5 in diameter in liver and 5 in ovaries; SP in ovary elongate, ellipsoidal, $15.2(14.0-15.4) \times 8.5(8.0-8.7) \times$

M. batalhensis Vieira, Alama-Bermejo, Bartholomew, Abdallah et Azevedo, 2017 (5.0-5.2), PC elongate and pyriform, equal, $5.2(5.0-5.5) \times 2.8$ (2.6-3.0), NC 6-9; SP in liver elongate and pyriform, equal, 15.3 $(14.0-15.5) \times 8.3(8.1-8.5) \times 5.0(4.9-5.0)$, PC elongate and pyriform $5.4(5.3-5.5) \times 2.8(2.8-2.9)$, NC 6-9; GBAN: MF 361090 (ovary specimens) and MF361091 (liver specimens). Fig. 15.

M. bejeranoi Lövy, $\mathrm{P}$ in striated muscle of gill filaments base; SP ovoid, $10.8(9.6-11.8) \mathrm{x}$ Smirnov, Brekhman, Ofek et6.8 (5.7-8.6); PC equal or nearly equal, 5.2 (4.1-6.4) × 2.2 (1.5-2.6) Lotan, 2018 NC 3-5; GBAN: MF 401455. Fig. 16.

$\mathrm{P}$ in connective tissue in cartilaginous arch close to base of gill filaments, $0.24-03 \times 0.08-0.13$; SP ellipsoidal in frontal view, citric shape in sutural view, $17.4(16.2-18.4) \times 13.1(11.9-13.9) \times 10.5$

M. bjoerknae Molnár,

Székely, Guti et Eszterbauer,(10-11), emerging suture evenly surrounding spores forming a rim
$2014 \quad$ frontal view, 0.8 $(0.7-0.11)$; PC drop-like, equal, $6.7(6.3-7.4) \times 4$. frontal view, 0.8 (0.7-0.11); PC drop-like, equal, 6.7 (6.3-7.4) $\times 4.1$
(3.6-4.5), NC 6; stout triangular IP, 2.1 (1.8-2.5); GBAN: KF314823. Fig. 17.

M. bragantinus Cardim, Silva, Hamoy, Matos et Abrunhosa, 2018

$P$ in gill filaments, intrafilamental-epithelial type, elongated, milky white, $0.3 \times 0.13$; SP spherical in frontal view, $6.2(5.9-6.3)$ in diameter; PC pyriform, equal, $2.4(2.1-2.8) \times 1.2(1.2-1.7)$; GBAN: MH183025.

M. cerveirensis Rocha, Casal, Alves, Antunes, Rodrigues et Azevedo, 2019

$\mathrm{P}$ in intestine; SP ellipsoidal in valvular and sutural view, at least 6 markings around posterior half of suture line, $8.1(7.7-8.7) \times 6.8$ $(6.7-7.3) \times 5.3(5.0-5.7), \mathrm{PC}$ pyriform equal, $4.2(4.0-4.7) \times 2.8$

(2.3-3.0), NC 4-5; GBAN: MK 203079. Fig. 18.

$\mathrm{P}$ in posterior kidney, spherical $0.056 \times 0.051$; $\mathrm{SP}$ oval with smooth shell valves, $11.0(9.8-12.0) \times 7.7(7.2-8.5) \times 7.6(7.3-8.1)$; PC

M. chanosi Chandran, Zacharia et Sanil, 2019 elongate oval, unequal, $6.6(5.2-7.5) \times 4.6(3.0-4.1)$ the larger, and $3.3(3.1-4.7) \times 2.5(1.5-3.2)$ the smaller, NC 4 in the larger and 3 in the smaller; GBAN: MK 950863. Fig. 19.

P elongatelly oval, white, $0.5 \times 2$ in gill lamellae (intralamellar vascular
type); SP spherical to ovoidal, up to 9 sutural marks at posterior end,

M. chushi Dar, Kaur et Chishti, 2017 type); SP spherical to ovoidal, up to 9 sutural marks at posterior end,
$11.1(10.6-11.4) \times 9.1(8.8-9.2) \times 6$; PC drop-like, equal, $4.2(4.0-4.4)$ $\times 2.3(2.0-2.6)$; IP absent; GBAN: KU885917. Fig. 20.

M. cultrati Borzák, Molnár, $\begin{aligned} & \text { P not found; batches of spores located in retina layer of eyes; SP } \\ & \text { elongate-ellipsoidal in frontal view, } 9.8(9.2-10.4) \times 6.4(6.0-6.8)\end{aligned}$ Cech, Papp, Deák-Paulus et elongate-ellipsoidal in frontal view, $9.8(9.2-10.4) \times 6.4(6.0-6.8)$; Székely, 2016 triangular IP, 1.9 (1.6-2.1); GBAN: KU170935. Fig. 21. $P$ whitish, ellipsoidal, up to 5 in length in gill filaments; SP round to P whitish, ellipsoidal, up to 5 in length in gill filaments; SP round to Prochilodus costatus
M. curimatae Zatti, Naldoni,oval in frontal view and biconvex in lateral view, 13.2 (12-14.7) $\times 9.7$ Valenciennes, São Francisco
Silva, Maia et Adriano, 2015(7-10.8): PC elongated, equal, 5.2(4.1-5.8) $\times 2.5(1.7-3.9)$, NC 9-10; River, Pirapora City, Minas Silva, Maia et Adriano, 2015(7-10.8): PC elongated, equal, 5.2 (4.1-5.8) × $2.5(1.7-3.9)$, NC 9-10; River, Pirapora City, Minas GBAN: KP120979. Fig. 22

$\mathrm{P}$ not found; SP in gills and intestine, spherical, with rounded posterior

M. danrici Mohilal et Soni, and anterior extremities in frontal view, and bi-convex in sutural vie 2017

$9.6(8.1-11.1) \times 9.5(8.1-10.1) \times 6.3$; prominent V-shaped IP; PC pyriform, equal, $6.4(5.0-7.1) \times 3.7(3.0-4.0)$, NC 5-6. Fig. 23 P not observed; SP in gills, shorter than wide, blunt, stout, more or

M. deformis Fariya, Abidi et less spherical, dorsoventrally flattened in frontal view, nearly oval or Chauhan, 2018

M. dermatoulcerans Stilwell, Stilwell, Camus, Ware, Rosser et Griffin, 2020

Labeo rohita (Hamilton);

Ranjit Sagar Wetland,

Punjab, India

Gupta and Kaur

(2018a)

Clarias batrachus

(Linnaeus); Lucknow, Uttar Fariya et al. (2018a)

Pradesh, India

Paracheirodon axelrodi

(Schultz); fish imported from Camus et al. (2017)

Brazil to USA

Cyprinus carpio Linnaeus; Lake Balaton, Hungary

Székely et al (2015a)

Labeo rohita (Hamilton);

Parikshitgarh Fish Farm,

Meerut, India

Székely et al (2015b)

Salminus hilarii

Valenciennes; Batalha River, Vieira et al. (2017) Brazil

Oreochromis aureus $\times$

Oreochromis niloticus; fish $\quad$ Lövy et al. (2018)
farm in Beit Shean Valley, Israel

Blicca bjoerkna (Linnaeus); Lake Balaton, Hungary

Molnár et al. (2014)

Mugil rubrioculus Harrison, Nirchio, Oliveira, Ron et Gaviria; Bragança, Pará State, Brazil

Chelon ramada (Risso);

River Minho (Vila Nova de Rocha et al. (2019b) Cerveira), Portugal

Chanos chanos (Forskål);

Alappuzha, Southwest coast Chandran et al. of India (2019)

Schizopyge niger (Heckel); Wullar Lake, Kashmir Himalayas, India

Dar et al. (2017a)

Pelecus cultratus

(Linnaeus); Lake Balaton, Borzák et al. (2016)

Gerais State, Brazil

Esomus danrica (Hamilton) Thoubal, Manipur, India

(2017)

Cyprinus carpio Linnaeus lenticural Lucknow, Uttar Pradesh, the larger 4.7 (3.8-5.8), the smaller 4.3 (3.2-5.4), NC 3-5. Fig. 24. $P$ in stratum compactum layer of dermis; SP pyriform, rounded posteriorly, rounded to tapering anteriorly, 16.1 (14.3-16.8) × 8.9 $\quad$ Pygocentrus nattereri Kner $(7.6-10.3) \times 6.4(6.0-6.9)$; PC slender, elongate, equal, 9.2 (7.4-10.2)
$\times 3.0(2.1-3.7)$, NC 11-13; IP absent; GBAN MT912631. Fig. 25.

Zatti et al. (2015)

Mohilal and Soni

Fariya et al. (2018b) India

Stilwell et al. (2020a) 
$\mathrm{P}$ white, round to irregular, in a cavity in scales, $0.5-3.6$ in diameter; M. dermiscalis Kaur, Attri etSP oval to spherical in frontal view, anterior and posterior ends Joshi, 2016 rounded, 5.8-7.8 × 3.9-5.9; $\mathrm{PC}$ equal, pyriform, 3.9-5.9 × 1.8-3.8, NC 5-6; IP absent; GBAN: KM092529. Fig. 26.

$\mathrm{P}$ in fins, ovoid or spherical, of variable sizes, $0.21-0.6 \times 0.125-0.41$ SP ovoid in frontal view and lenticular in lateral view, with truncated M. dibombensis Folefack, anterior end and rounded posterior one, 6 to 8 valvular folds at Abdel-Baki, Ateba, Fomena posterior end, $16.8(15.8-18) \times 11.4(10-13)$; PC ovoid, slightly et Mansour, 2019

unequal, $7(6-8) \times 3.6(3-4)$, NC 11, the larger, 5.8 (4.8-7) $\times 3$ (2-4), NC 7-9, the smaller; conspicuous IP, $2.9(2.2-3.8)$; GBAN: MG737377. Fig. 27.

$P$ about 1 in diameter, in intrafilamential-epithelial location in gills SP rounded but compressed in thickness, $11.7(10.7-12.3) \times 8.6$

M. doubleae Milanin, Bartholomew et Atkinson, 2020

$(7.7-9.0) \times 5.2(4.6-5.4) ;$ PC pyriform, slightly dissimilar in size, 5.7 $(5.1-6.5) \times 2.7(2.4-3.2)$, NC 8-9; GBAN: seq.1 MK592012, seq. 2 MK5902013. Fig. 28 .

M. duriensis Rocha, Azevedo, Alves, Antunes et in valvular view and ellipsoidal in sutural view, with smooth valves, Casal, 2019 $4.9(4.3-5.3) \times 3.4(3.3-3.7)$, NC 6; GBAN: MK053783. Fig. 29. $\mathrm{P}$ attached to mucous membrane around gill lamellae, 1-2 in size; SP elongated in valvular view, lancet-shaped, valves smooth, 16.2

M. elongatum Ghosh et Bandyopadhyay, 2017 $(13-17.6) \times 7.9(7-9)$; PC slender and elongated, unequal in size, 8 . $(7-10) \times 3.4(3-4)$ the larger, and $6.5(6-7) \times 3.4(3-4)$ the smaller. Fig. 30 .

$P$ white and spherical, in skin, up to 3 in diameter; SP ovoid in

M. figueirae Naldoni, Maia, frontal view, biconvex in lateral view, $9.5(9.1-10) \times 6.4(5.8-6.9) \times$ Correa, Silva et Adriano, 2018

4.5 (4.4-4.5); PC unequal in size, $4.1(3.5-4.6) \times 2.1(1.7-2.6)$ the larger, and $3.2(2.4-3.6) \times 1.4(1.2-2.1)$ the smaller, NC 7-8; GBAN MG181226. Fig. 31.

M. filamentum Naldoni, Zatti, Capodifoglio, Milanin, Maia, Silva et Adriano, 2015 M. galaicoportucalensis Rocha, Casa, Alves, Antunes, Rodrigues et Azevedo, 2019

$P$ whitish, elongated, in gill filaments up to 5 in size; SP pear-shaped in frontal view, biconvex in lateral view, with symmetric valves 9.0 $(7.5-9.7) \times 6.2(5.2-7.3) \times 5.3(4.8-5.7) ; \mathrm{PC}$ elongated, equal, 4.7 $(3.8-5.5) \times 1.7(1.3-2.2)$, NC 10-11; GBAN: KJ849240. Fig. 32. $\mathrm{P}$ in intestine; SP ellipsoidal in valvular and sutural view, 12-14 markings near suture line, $11.9(11.3-12.7) \times 10.2(10.0-10.7) \times 6.7$ (6.0-9.0); PC pyriform, equal, 4.7 (4.0-5.3) $\times 2.9(2.7-3.3)$, NC 4-5; GBAN: MK203084. Fig. 33.

$P$ rounded, $0.16(0.10-0.19) \times 0.12(0.09-0.16)$ in intralamellar tissue adjacent to vessels in gill filaments; SP pyriform in valvular view and lemon shaped in sutural view, $12.5(11.7-13.9) \times 9.2(8.5-9.8) \times 7.0$

M. ginbuna Kato, Kasai, Tomochi, Li et Sato, 2017 (6.7-7.3); PC pyriform, slightly unequal, 7.2 (6.6-7.6) $\times 2.9(2.7-3.2)$ Temminck et Schlegel;
the larger, and 6.7 (6.1-7.1) $\times 2.9(2.4-3.4)$ the smaller, NC 8-9; thin (Kudengawa River), rod-like IP extending from inside wall of apex; GBAN: LC228238. Yamaguchi City, Japan Fig. 34.

SP in kidney, ellipsoidal or cylindrical in frontal view, $8.0(7.2-8.9)$

M. gomtii Abidi, Fariya et $\quad \times 4.8(4.0-5.1)$; PC straight, equal, tapered towards anterior end, 4.1 Chauhan, 2016 $(3.2-5.4) \times 1.5(1.0-1.9)$, NC 4-6. Fig. 35

$\mathrm{P}$ whitish, oval, round or ellipsoidal, $1.4 \times 0.9$, out of throat serous surface; SP ellipsoidal, unsymmetrical in frontal view, lemon-like in M. gutturocola Liu, Zhang lateral view, smooth, $12.5(11.6-13.7) \times 8.4(8.4-10.7) \times 7.1(6.8-7.3)$ et Zhao, 2019 $\mathrm{PC}$ pyriform, unequal, the larger 5.7 (4.9-6.4) $\times 3.6(3.0-4.1), \mathrm{NC}$ $7-8$, the smaller 4.6 (4.0-5.5) × 2.6 (2.1-3.6), NC 4-5; IP v-shaped; GBAN: MF 543857, MF543858 and MF 543859. Fig. 36.

P. round, in gills, 0.4-0.5; SP rounded, bowl-shaped in frontal view,

M. hardevi Gupta et Kaur, 2020

\section{broad and flattened anterior end and rounded posterior one, $8.9 \times 6.2$} prominent thickening between polar capsules; PC unequal, round to bottle-shaped, the larger $3.3 \times 2.7$, the smaller $1.3 \times 1.3$, NC 5-6 $2-3$ in the larger and smaller, respectively; IP absent. Fig. 37.

P small, rounded, white, 1-2 in diameter, attached to mucous

membrane around gill lamellae; SP ellipsoidal in frontal view, 13.2 Labeo bata (Hamilton);

M. harpreetae Ghosh et

Bandyopadhyay, 2017

$(11.4-13.8) \times 6.5(4.9-7.8)$; PC unequal, $9.1(8.7-9.2) \times 3.4$
the larger, $7.9(7.6-8.3) \times 6.5(4.9-7.8)$ the smaller. Fig. 38 .

$P$ in liver and gall bladder Wall; SP ellipsoidal in valvular and sutural

M. hepatobiliaris Rocha, Casal, Alves, Antunes, view, 6-8 markings near the suture line, $6.6(6.0-7.0) \times 5.2(4.7-5.7)$ Rodrigues et Azevedo, $2019 \times 4.1$ (4.0-4.3); PC pyriform, equal, $3.0(2.7-3.3) \times 1.7(1.7-2.0)$, NC 4; GBAN: MK203078. Fig. 39.

M. hilarii Capodifoglio, Adriano, Milanin, Silva et Maia, 2015

$\mathrm{P}$ in kidney, round, up to 0.5 ; SP round, $11.5(9.8-13.4) \times 11$ $(9.7-12.4) \times 7.6(6.7-9.0) ;$ PC elongated, equal, $6.5(6.0-7.2) \times 4.0$ (3.6-5.3), NC 5-7; GBAN: KM403404. Fig. 40.

Labeo rohita (Hamilton); Lucknow, Uttar Pradesh, India

Abidi et al. (2016)

Hypophthalmichthys molitrix

Valenciennes; Hechuan

District, Chongqing, China

Liu et al. (2019a)

Labeo bata (Hamilton),

Ranjit Sagar Wetland,

Punjab, India

olefack et al. (2019)

Milanin et al. (2020)

Rocha et al. (2019a)

Ghosh and

Bandyopadhyay

(2017)

Naldoni et al. (2018)

ioliopterus (Bloch et

Naldoni et al. (2015)

Pirapora, Minas Gerais State,

ugil cephalus Linnaeus;

River Minho (Vila Nova de Rocha et al. (2019b)

Labeo bata (Hamilton); Ghosh and Bandyopadhyay (2017)

Gupta and Kaur (2020)

Chelon ramada (Risso);

River Minho (Vila Nova de Rocha et al. (2019b) Cerveira), Portugal

\section{Brycon hilarii}

(Valenciennes); fish farm, Capodifoglio et al. Municipality of Mogi Mirim, (2015)

São Paulo State, Brazil

P large, 2-10, creamish, elongated, in blood vessels of gill filaments; Schizothorax richardsonii SP oval to spherical in frontal view with compressed anterior end and (Gray); River Poonch, acuminate and broadly rounded posterior end, parietal folds present, 9.64District of Jammu and $\times 7.06$; PC pyriform, equal, $4.89 \times 2.70$, NC 5-6: IP absent. Fig. 41 . Kashmir, India

$\mathrm{P}$ cylindrical and white, in gill lamellae, $0.5-4$ in diameter. SP round to Labeo rohita (Hamilton);

M. himalayaensis Ahmed Ahmad, Dar, Awas, Kaur Ganai et Shah, 2019 M. holzerae Gupta et Kaur, elliptical in valvular view, lemon-shaped in side view, 7.6 (7.6-7.7) $\times$ Labeo rohita (Hamilton)
2017
$4.2(4.1-4.3)$; PC pear shaped, equal, $2.54(2.54-2.58) \times 1.6(1.5-1.6)$, Panjit Sagar Wetland in
Ahmed et al. (2019)

Gupta and Kaur

(2017a) NC 5-6; IA absent; GBAN: KX 757027. Fig. 42. 
M. ictiobus Rosser, Grifin, Quiniou, Alberson, Woodyard, Mischke, Greenway, Wise et Pote, 201643.

round, intralamellar, in gill filaments, $0.148 \times 0.122 ; \mathrm{SP}$ spherical, Ictiobus bubalus $13.9(12.7-14.5) \times 12.5(10.7-13.6) \times 12.6(10.3-14.8)$; PC pyriform, (Rafinesque); catfish (5.6-7.4) ×4.5(3.7-4.9), NC 5-6; GBAN: KU232371. Fig aquaculture pond, Washington County, Mississippi, USA

$\mathrm{P}$ in liver, whitish, spherical, $<10$ in diameter; SP oval, anterior

Salminus franciscanus Lima

M. iecoris Naldoni, Zatti, region aculiform in frontal view, $12.8(11.4-14.2) \times 8.7$ (7.7-9.9) × 6.9et Britsky; São Francisco

Silva, Maia et Adriano, 2019(6.5-7.5); PC equal, 5.9 (4.9-7.4) × $3.0(2.3-3.5)$, NC 8-9; GBAN: River, Minas Gerais State , MH500002. Fig. 44.

SP in primary and middle third of primary gill filaments developed

M. imparfinis Vieira, Tagliavini, Abdallah et Azevedo, 2018 in afferent branchial artery, round $7.9(7.1-8.4) \times 5.5(4.5-6.2) \times 3.7$ Imparfinis mirini Haseman; $(3.1-3.8) \times 1.5(1.2-1.8)$ the smaller, NC 6-7; GBAN: MF425815 and Paulo State, Brazil MF 425816. Fig. 45.

$\mathrm{P}$ whitish, in gill filaments and fins, up to eight per fish, a single $\mathrm{P}$

M. indica Saha et Bandyopadhyay, 2017 was $0.7-1.1$; SP subspherical, with blunt anterior and posterior en in frontal view, $5.8(5.6-7.2) \times 4.1(3.5-4.9)$; PC pyriform, equal, 4.1 $(3.5-4.9) \times 2.7(1.8-3.5)$, NC 4-5; small IP. Fig. 46 Diamond Harbour, South $\mathrm{P}$ rounded, up to 0.045 in diameter, in distal region of gill filaments;
SP ovoid in frontal view, $17.6(16.2-19.8) \times 10.5(9.8-12) ; \mathrm{PC}$

M. iquitoensis Mathews Meertins, Milanin, Espinoza, SP ovoid in frontal view, 17.6 (16.2-19.8) $\times 10.5(9.8-12)$; PC
Flores-Gonzalez, Audebert etelongated, equal, 8.7 (6.9-9.3) × 3.3 (3-3.6); NC 6-7; GBAN: Flores-Gonzalez, Audebert etelongated, equal, 8.7
Morandini, 2020

A single $\mathrm{P}$, white, oval $(3.1 \times 2.8)$ in hepatopancreas of one fish, and a white one, spherical, 3 in diameter, in urinary bladder of other fish SP (in the urinary bladder with a membraneous sheath) pyriform,

M. jialingensis Gao, Zhang, $15.8(15.4-17.0) \times 8.0(7.8-8.9)$; PC pyriform unequal pyrorm, Yang et Zhao, 2020 $(6.7-8.0) \times 3.1(2.8-3.6)$, the smaller $7.3(6.6-8.1) \times 3.3(2.9-3.6)$ NC 7-8; GBAN: MN 066413 (spores from urinary bladder) and MN066414 (hepatopancreas). Fig. 48.

$\mathrm{P}$ in gill lamellae, disporoblastic, round, less than $2 \mathrm{~mm}$; SP ellipsoidal Cirrhinus cirrhosus (Bloch);

M. kalavatiae Székely, Cech Chaudhary, Borzák Singh et Molnár, 2015 both in frontal and sutural view, $7.3(6.8-7.7) \times 5.3(4.8-5.8) \times 3.7$ (1.6-2.0); GBAN: KM029973. Fig. 49.

P minute, round to oval, $0.1-0.3$, in gill lamellae; SP pyriform in M. kashmirensis Dar, Kaur frontal view, with constriction in neck region, bluntly pointed at et Chishti, 2017 anterior end and rounded posteriorly, $9.16 \times 3.33$; PC pyriform, equal, $3.33 \times 0.83$, NC 6; IP absent. Fig. 50 .

$\mathrm{P}$ whitish, ellipsoidal, or round, 2-4 in diameter, in intestinal wall; SP subspherical to elliptical, sometimes oval in frontal and lateral view, Acanthopagrus bifasciatus

M. khaliji Zhang, Al-

With a prominent thick caudal end, 8.1 (7.2-9.5) $\times 6.3(5.1-7.4) \times 9.2$ (8.3-10.2); PC elliptical, equal, $5.5(4.1-6.1) \times 3.2(2.1-4.2)$, NC 3; Arabia GBAN: KC711053. Fig. 51.

$P$ swellings $5-10$ in size, immediately posterior to host head and M. klamathellus Atkinson et on lateral regions of body; SP ovoid, compressed in thickness, 14.3 Banner, 2017 $(13-15) \times 9.7(9.5-10) \times 7.7(7.5-8)$; PC pyriform, slightly inequal in size, $6.4(6-7) \times 3.8(3-4)$, NC 3-5; GBAN: KX261616. Fig. 52.

$P$ minute, round to irregular, white, 0.4 in diameter, attached to

M. knobii Kaur et Ahmad, gill lamellae; SP oval to spherical, pot-shaped in frontal view, with 2017 a prominent anterior knob, shell smooth, $5.8 \times 4.2 ;$ PC broadly pyriform, equal, $1.9 \times 1.7$, NC 3-4; IP absent. Fig. 53 .

$\mathrm{P}$ in urinary bladder; SP oval in valvular view and ellipsoidal in

M. labrosus Rocha, Casa, Alves, Antunes, Rodrigues et Azevedo, 2019 sutural view, about 8 markings near suture line, $10.0(9.7-10.3) \times$ $8.1(7.7-8.7) \times 5.8(5.7-6.0)$; PC pyriform, equal, $4.5(4.0-5.0) \times 2.5$ (2.3-2.7), NC 5-7; GBAN: MK203081. Fig. 54

$\mathrm{P}$ in multilayered epithelium of gill filaments close to base of filaments; SP round or roundish, lemon-shaped in sutural view, sutural protrusion in frontal view forming a thick $1.0(0.9-1.1)$ circular rim

M. lamellobasis Molnár, Székely, Guti et Eszterbaue 2014 , around spore, emerging in sutural view, $1.0(0.8-1.1)$ both at anter and posterior end, $6-8$ edge markings clearly seen in sutural rim;

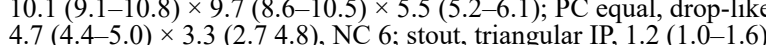
GBAN: KF314824. Fig. 55.

$\mathrm{P}$ in edge of primary gill lamellae, elongate-oval, $0.988 \times 0.485$ (L. marginatus) and $0.8 \times 0.6$ (Lepomis miniatus (Jordan)); SP 19.0 $(16.8-21.3) \times 7.9(7.0-8.8) \times 5.8(5.3-6.1)$ in $L$ marginatus, and 18.8 (Holbroock); Big Dand

M. lepomis Rosser Baumgartner, Barger et Griffin, 2017 $(17.2-20.3) \times 8.7(5.3-6.1)$ in L. marginatus; PC pyriform, equal, $9.0(8.3-9.8) \times 2.5(2.2-2.7)$ in L. marginatus, and $10.0(9.2-1.5)$ $\times 2.8(2.2-3.0)$ in L. miniatus, NC 10-12; GBAN: KY203390 and KY203391. Fig. 56.

$\mathrm{P}$ whitish, spherical, in spleen; SP round to oval in frontal view, biconvex in lateral view, $12.0(10.3-13.8) \times 8.3(6.8-9.3) \times 7.0$

M. lienis Naldoni, Zatti, $9(6.0-7.0)$; PC oval, equal, $4.6(3.9-5.8) \times 2.8(2.0-3.5)$, NC 5-6; GBAN: MH 500003. Fig. 57.

$\mathrm{P}$ whitish, ovate or ellipsoidal, under epithelium of gill filaments,

M. linzhiensis Li, Xi, Zhao $1.7 \times 0.4$; SP suborbicular in frontal view, fusiform shaped in lateral
view with tapering anterior, $11.4(10.1-13.0) \times 10.6(10.0-11.3) \times 6.6$ et Xie, 2017

(6.2-7.0); PC pyriform with an apophysis at the top end, equal, 5.7 $(4.8-6.7) \times 3.8(3.2-4.2)$, NC 4; GBAN: KY 965935. Fig. 58.

$\mathrm{P}$ white, 0.2, biconvex in lateral view, in external wall of stomach,

M. longissimus Capodifoglio, Adriano, Silva et Maia, 2019 intestine and gill arch; SP $19.1(18.0-20.0) \times 9.4(8.6-10.4) \times 8.3$ (7.6-8.9); PC elongated, equal, $10.5(9.7-11.1) \times 2.5(2.1-2.4)$, NC 9-10; GBAN: MK032221. Fig. 59.
Gila coerulea (Girard);

A-canal, Upper Klamath Lake, Oregon, USA

Cirrhinus mrigala

(Hamilton); Fagan Majra, Kaur and Ahmad District of Fatehgarh Sahib, (2017)

Punjab, India

Chelon labrosus (Risso)

River Minho (Vila Nova de Rocha et al. (2019b) Cerveira), Portugal

Blicca bjoerkna (Linnaeus) Lake Balaton, Hungary

Creek, Big Thicket Natural Rosser et al. (2017)

Preserve in Polk County,

Texas, USA

Brycon orthotaenia Günther, São Francisco River, Pirapra, Naldoni et al. (2019) Minas Gerais State, Brazil

Schizothorax oconnori Lloyd; Yarlung Tsangpo Lloyd; Yarlung Tsangpo
River in the Tibetan plateau, Li et al. (2017) China

Colossoma macropomum (Cuvier); Tapajós River, Municipality of Santarém, (2019) Pará State, Brazil
Atkinson and Banner (2017)

Molnár et al. (2014)

Rosser et al. 2016

and

andyopadhyay

Mathews et al. 2020b)

Gao et al. (2020) Székely et al. Dar et al. (2017b)

Zhang et al. (2014)

Capodifoglio et al. 
M. lucknowii Abidi, Fariya, P small, white, embedded in kidney; SP circular in frontal view, lemon- Clarias batrachus

$\begin{array}{llll} & \text { size, } 3.7(3.1-4.1) \times 2.2(2.1-2.6) \text {; noticeable IP present. Fig. } 60 . & \text { Uttar Pradesh, India. } \\ & \text { P whitish and ovoid between secondary gill lamellae, 0.17-0.30 } & \\ \text { M. magai Deli, Folefack et } & 0.116-0.2 \text {; SP ovoid, anterior end larger and hillocky, posterior end Labeo batesii Boulenger; } \\ \text { Fomena, 2017 } & \text { narrow, 10.6 }(9.0-12.0) \times 6.3(5.5-7.0) \text {; PC equal, ovoid, 2.8 (2.4-3.4) Maga, Cameroon }\end{array}$ $\times 2.3(2.0-3.0)$, NC $4-5$. Fig. 61 .

P round to oval, creamish, 0.4 in diameter, attached to gill lamellae; SP Gibelion catla (Hamilton) egg-shaped in frontal view, ellipsoidal in sutural view, valves smooth, Phaagan Majra, District of egg-shaped in frontal view, ellipsoidal in sutural view, valves smooth, Fatehgarh Sahib, Punjab,
$8.5 \times 5.2$; PC pyriform, equal, $3.4 \times 1.8$, NC 5-6; IP absent. Fig. 62 .
India

Kaur and

$\mathrm{P}$ in liver and kidneys; SP ellipsoidal in frontal view, $13.3(10.5-16.5)$ Oreochromis niloticus $\times 6.8(6-9)$; PC unequal in size, $6.4(6-8.2) \times 2.8(2.2-4.5)$ the larger, Oreochromis niloticus $4.1(3.5-5.2) \times 1.6(1.5-2.2)$ the smaller; other host: Enteromius callipterus (Boulanger) (same sampling place); note: the authors did Bameroon not indicate a type-host or a type-locality. Fig. 63.

P ellipsoidal to oval-shaped, whitish, $0.345(0.213-0.408) \times 0.195 \quad$ Rhamdia quelen (Quoy et

M. mapei Georges,

Joseph, 2017

M. marajoensis Abrunhosa, (0.122-0.245) in the muscular layer of the intestine; SP pyriform, 10.9 Gaimard), Baracauari River, Sindeaux-Neto, Santos, Hamoy et Matos, 2018 $(10.0-11.6) \times 5.1(4.2-5.4) ;$ PC equal, $5.3 \pm 0.6 \times 1.6 \pm 0.3$; GBAN: KX857727. Fig. 64.

Salvaterra, Marajó Island, Pará State, Brazil

$P$ minute, round to oval, creamish, 0.2 in diameter, attached to gill M. markiwi Kaur et Ahmad, lamellae; SP ovoidal in frontal view, bluntly pointed anteriorly, with 2016 prominent knob, smooth, $6.5(5.6-7.4) \times 5.3(4.3-6.3)$; PC pyriform equal, $1.8(1.2-2.4) \times 0.8(0.3-1.3)$, NC 4-5, IP absent. Fig. 65 .

Labeo rohita (Hamilton);

Phagan Majra, District

Fatehgard Sahib, Punjab, India $P$ in pleural ribs through length of abdominal cavity, surrounded by ossified bone, up to 5 in diameter; SP round or ellipsoidal, $11.1 \pm 0.5$ $\times 12 \pm 0.5 \times 7.8 \pm 0.4 ; \mathrm{PC}$ pyriform, equal, $6.3 \pm 0.4 \times 4.2 \pm 0.3, \mathrm{NC}$

M. mauriensis Lovy et Hutcheson, 2016 5-7; IP small or not apparent; GBAN: KU255436; other host and localities: Alosa pseudoharengus (Wilson), Great Egg Harbor River

Alosa aestivalis (Mitchill); Maurice River, New Jersey, USA

Deli et al. (2017) and Delaware River, New Jersey, USA. Fig. 66.

$\mathrm{P}$ elongated, reaching more than 4.5 in length, in somatic muscles; SP M. marumotoi $\mathrm{Li}$ et Sato, rounded in valvular view and ovoid in sutural view, $13.8(13.3-15.0) \times$ 2014 $14.6(14.2-15.0) \times 10.8(10.0-11.7)$; PC subspherical, 8.4 (7.9-9.6) 5.9 (5.4-6.3), NC 5-6, IP present; GBAN: AB873007. Fig. 67.

Odontobutis obscura (Temminck et Schlegel); Yoshida, Yamaguchi, Japan

Georges et al. (2017)

Abrunhosa et al.

(2018b)

Kaur and Ahmad (2016)

Lovy and Hutcheson (2016)

Li and Sato (2014)

Colossoma macropomun

(Cuvier); Solimões River,

$\mathrm{P}$ in inner surface of operculum, 0.1 SP ellipsoidal in frontal

M. matosi Capodifoglio, Adriano, Silva et Maia, 2019 view, biconvex in lateral view, $9.6(9.1-10.8) \times 7.0(6.5-7.6) \times 5.0$ (4.6-5.5); PC elongated, equal, $4.3(3.3-5.0) \times 1.9(1.6-2.2)$; GBAN MK032219; note: the authors did not indicate a type-locality. Fig. 68

Municipality of Manacapuru, Capodifoglio et al.

Santarém, Pará State, Brazil

P small, less than $2 \mathrm{~mm}$, in capillary network of gill lamellae; SP ellipsoidal in frontal view and lemon-shaped in sutural view, sutural

M. meerutensis Székely, Cech Chaudhary, Borzák Singh et Molnár, 2015 protrusion forming a circular rim around spore, emerging about 0.6 to
0.8 on surface of spore, $9.1(8.8-9.6) \times 6.9(6.4-7.2) \times(5.1(4.9-5.2)$ small knob-like IP, 0.4-0.5; PC elongated, equal, $4.3(4.1-4.5) \times 2.1$ (1.6-2.4), NC 6; GBAN: KM029977. Fig. 69.

P. round, in mesentery, about 3.0; SP round in frontal view and

M. mineirus Naldoni, Carriero, Moreira, Silva, Maia et Adriano, 2020 biconvex in lateral view, $13.4(12.8-14.2) \times 10.6(10.0-10.6) \times 6.5$ (6.0-6.9), valves symmetrical; PC elongated, equal, $5.3(4.4-6.1) \times$ 3.1 (2.3-3.8), NC 8, GBAN: MT302590. Fig. 70.

M. minutus Rosser Griffin, Quiniou, Alberson, Woodyard, Mischke, Greenway, Wise et Pote, 2016

P elongate, approximately $1.3 \times 0.4$, along edge of gill primary lamellae; SP ovoid, $8.8(7.4-9.6) \times 8.8(7.5-9.9) \times 6.7(6.5-7.3)$ PC pyriform, equal, $4.3(3.6-4.9) \times 3.3(2.8-3.8)$, NC 5-6; GBAN: KU232372. Fig. 71.

Labeo rohita (Hamilton); Parikshitgard Fish Farm, Meerut, Uttar Pradesh, India

Székely et al. (2015b)

Brycon orthotaenia Günther,

São Francisco River, Naldoni et al. Brazil

Ictiobus bubalus

(Rafinesque); catfish

aquaculture pond,

Washington County,

Rosser et al. (2016)

$\mathrm{P}$ white, slightly elongated, oval, $0.3-0.5$, in basal subepithelial tissue between gill filaments; SP ellipsoidal in frontal view and lemonshaped in sutural view, $13.6(12.8-14.2) \times 10.7(10.3-11.4) \times 7.8$

M. mucosus Liu, Voronin, (7.2-8.3); PC drop-like, equal in size, 5.5 (4.8-6.0) × $3.6(3.2-3.8)$, Dudin et Zhang, 2016 NC 5-6, distinct stout and triangular IP, $1.6(1.5-8)$ in diameter;

Mississippi, USA

Rutilus rutilus (Linnaeus);

Finnish Bay of Baltic Sea GBAN: KP751907, KP751908, KP751909. Other host: Leuciscus and Lake Ladoga, Russia

Liu et al. (2016a)

leuciscus (Linnaeus); note: the authors did not indicate a type-host or a type-locality. Fig. 72 .

P. whitish, subspherical to filamentous, in gill lamellae, 1-2 in

M. mugiliensis Rocha

Casal, Alves, Antunes, length; SP ellipsoidal in valvular and sutural view, $8-10$ markings near sutural line, $11.4(11.0-11.7) \times 9.6(9.0-10.3) \times 6.5(6.0-6.7)$;

Rodrigues et Azevedo, 2019 PC pyriform, equal, 4.9 (4.7-5.3) × 3.0 (2.7-3.3), NC 5; GBAN: MK203082. Fig. 73.

$P$ round, 2-3 in diameter, creamy white, attached to mucous

M. muralidharani Ghosh et membrane of gill lamellae; SP elongated, smooth, lancet-shaped, 13.8 Bandyopadhyay, 2016

$(13-14) \times 5.3$ (4.9-6); PC equal, slender, and elongate, $7.3(6.9-8.0)$ 2.5 (1.9-2.9). Fig. 74

$\mathrm{P}$ in heart fibers and skeletal muscle; $\mathrm{SP}$ oval in valvular view and M. muscularis Rocha, Casal,ellipsoidal in sutural view, 8-10 markings surrounding posterior Alves, Antunes, Rodrigues half of suture line, $9.1(8.0-10.0) \times 7.0(6.0-8.7) \times 5.2(4.7-6.0)$; et Azevedo, 2019 PC pyriform, equal, $4.3(4.0-5.0) \times 2.7(2.0-3.3)$, NC 5-6; GBAN: MK203075. Fig. 75.

$\mathrm{P}$ in gill lamellae, round to ovoid, $0.038-0.040$ in diameter; SP

M. nanokiensis Kaur, pyriform with sharply pointed beak-like in anterior end and rounded Labeo rohita (Hamilton),

Katosh, Dar et Singh, 2015 in posterior one, 9.2 × 5.7; PC broadly pyriform, equal, $5.7 \times 2.7$, NC Patiala (Punjab), India

Mugil cephalus Linnaeus;

River Minho (Vila Nova de Rocha et al. ( 2019b) Cerveira), Portugal

Labeo rohita (Hamilton);

Hansnkhali of Nadia, West

Bengal, India

Ghosh and

Bandyopadhyay

(2016)

Chelon ramada (Risso);

River Minho (Vila Nova de Rocha et al. (2019b)

Cerveira) Portugal 7-9; IP absent. Fig. 76. 
SP pyriform, intercellular infecting nerve cord and medulla oblongata, M. neurofontinalis Ksepka having two valves juxtaposed at sutural rim, $13.9(12.0-16.9) \times 9.6$ M. neurofontinalis Ksepka, $(8.0-12.0) \times 8.1(7.0-10.0)$, sutural rim with prominent seam, with 2019 Whelan et Bullard, $\quad$-4 sutural markings; PC clavate, equal or subequal in size, 7.8 $(6.0-10.0) \times 3.5(3.0-5.0)$, NC 7-10; IP 2.3 (1.0-3.0) long by 1.5

Salvelinus fontinalis (Mitchill); East Fork South $\quad$ Ksepka et al. (2019)
Fork New River, western $\mathrm{NC}$, USA

\section{(1.0-2.5) wide; GBAN: MN191598. Fig. 77.}

$\mathrm{P}$ whitish between bony rays of fins, operculum, skin and sclera of eye, ovoid or elongated, $0.315 \times 0.205$; SP ovoid in frontal view, 11.5 $(10.7-12.8) \times 9.4(8.3-10.5), 5-6$ valvular folds at posterior half of

M. ngassami Folefack, Defoueng et Fomena, 2017 spore; PC ovoid and inequal in length, $50(4.5-5.6) \times 2.8(2.1-3.4)$, NC 7-10 the larger, $4.4(3.5-5.1) \times 2.4(1.7-3)$ the smaller, NC 5-7, IP 2.3 (2-2.8). Fig. 78.

$\mathrm{P}$ in serosa layer of gill arch, spherical to ellipsoidal, $0.18 \pm 0.01$ in

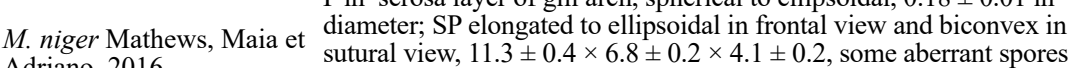
Adriano, 2016

with three polar capsules but presenting measurement values of norm spores; PC elongated, equal $5.0 \pm 0.3 \times 2.0 \pm 0.1$, NC 6-7. Fig. 79 .

$\mathrm{P}$ minute, round to ovoid, 0.08-0.1 in diameter, in gills lamellae; SP ovoidal or subspherical in frontal view, $6.6(6.3-6.9) \times 5(4.8-5.2)$. $P C$ oval, equal, $3.3(3.1-3.5) \times 1.6(1.5-1.7)$, NC 5; IP absent. Fig. 80 .

M. nigerae Dar, Kaur et Chishti, 2016 oval, equal, $3.3(3.1-3.5) \times 1.6(1.5-1.7)$, NC 5; IP absent. Fig. 80 . petal (1-2), attached to mucous membrane around gill lamellae, SP Labeo rohita (Hamilton);

M. nilimae Ghosh et Bandyopadhyay, 2016
$\times 3.1(3.0-3.5)$, NC 10-12. Fig. 81 .

$P$ large, cylindrical, in gills, 5-7 per gill filament, $0.9-3$ in diameter; $\mathrm{SP}$ M. okamurae Gupta et Kaur,pyriform in valvular view, $12.2 \times 4.9$ in diameter; PC pyriform, equal, 2018 $6.1 \times 1.4$, NC 13.14; prominent intercapsular process present; GBAN: KX146838. Fig. 82 .

$\mathrm{P}$ in kidney, round, 0.15-0.2 in diameter; SP large, elongated pyriform,

M. ompok Chaudhary, Goswami, Gupta, Cech, Singh, Molnár, Székely et Sharma, 2018

both in frontal and sutural views; SP $14.4(13.6-14.48) \times 6.5(5.6-6.4)$ $\times 5.9(5.2-6.4)$; PC very elongated, narrowing anteriorly, equal, 8.2 $(8.0-8.5) \times 1.8(1.5-2.4)$, NC 6; IP not present; GBAN: MG760574 and MG760575. Fig. 83 .

$\mathrm{P}$ round or ellipsoidal, 2.6-4.0 histozoic in palate; SP obovate in frontal view and lemon-shaped in lateral view, 2-5 V-shaped sutural

M. oralis Liu, Whipps, Nie ridge markings, small proportion of spores (11\%) with short tail or Carassius gibelio (Bloch); et $\mathrm{Gu}, 2014$

much more clearly visible tail (up to 5.2 in length), 11.7 (10.8-12.8) $\times 8.9(8.2-9.9) \times 6.8(6.0-7.5) ;$ PC pyriform, equal $4.8(4.0-5.5) \times 3.0$ (2.9-3.6), NC 5-6; IP small; GBAN: KC315782. Fig. 84.

M. orthotaenae Naldoni, Pereira, Milanin, Adriano Silva et Maia, 2020

$\mathrm{P}$ white and spherical, up to 1.0 in liver; SP ellipsoidal in frontal view, $10.7(10.0-11.4) \times 8.1(7.3-8.6) \times 6.8(5.3-7.0)$; PC equal, 4.9 $(4.2-5.4) \times 2.7(1.9-2.9)$, NC 8; GBAN: MN719635. Fig. 85 .

M. ovarium Naldoni, Pereira, Milanin, Adriano, Silva et Maia, 2020

P spherical, up to 1.0, in surface of ovary; SP oval-shaped in frontal view, $9.8(9.2-11.0) \times 6.5(5.6-6.9) \times 4.9(4.6-5.0)$; PC equal, 4.7 (3.9-6.2) × $2.1(1.8-2.4)$, NC 8-9; GBAN: MN719638. Fig. 86.

$\mathrm{P}$ large, flat, 1.0-1.7, in connective tissue of swim bladder, covered by P thin epithelial layer; SP ellipsoidal in frontal view and lemon-shaped a thin epithelial layer; SP ellipsoidal in frontal view and lemon-shaped
in sutural view, $14.8(14.4-15.2) \times 11(10.4-12) \times 8.7(8.4-9.2)$; PC

M. paksensis Cech, Borzák Molnár et Székely, 2015

in sutural view, $14.8(14.4-15.2) \times 11(10.4-12) \times 8.7(8.4-9.2)$; PC
pyriform, equal, $7.0(6.8-7.6) \times 4.3(4.0-4.6)$, NC 6; IP relatively smal

Enteromius callipterus

(Boulenger); Sanaga River,

Cameroon

(2017)

Corydoras melini Lönnberg et Rendahl; River Negro, near Municipality of Santa

Isabel do Rio Negro,

Amazonas State, Brazil

Mathews et al.

(2016)

Schizopyge niger (Heckel)

Wular Lake, Kashmir, India India

Labeo bata (Hamilton);

Ranjit Sagar Wetland,

Punjab, India

Ompok pabda (Hamilton) Sotiganj, Meerut, Uttar Pradesh, India

Gupta and Kaur (2018b)

Chaudhary et al. (2018)

Hubei Province, China

Brycon orthotaenia Günther São Francisco River Municipality of Pirapora, Minas Gerais State, Brazil Brycon orthotaenia Günther, São Francisco River, Municipality of Pirapora, Minas Gerais State, Brazil

Naldoni et al. (2020b)

Chondrostoma nasus

(Linnaeus); River Danube, Cech et al. (2015) Naldoni et al. (2020b) triangular, 1.6-2.3; GBAN: KP025687-KP025689. Fig. 87.

Single P, white, spherical, 0.23 in gill lamellae; SP elongated, pyriform in frontal view, valves smooth, with pointed anterior end and round posterior Cyprinus carpio Linnaeus; one, 15.9 (14.5-17.2) × 7.8 (6.6-9.7); PC pyriform, equal, 8.7 (7.7-9.8) $\times$ Jialing River, Shapingba $3.0(2.6-3.5)$, NC 11-12; GBAN: MH196558. Fig. 88.

$\mathrm{P} 0.23 \times 0.20$ and $0.32 \times 0.29$ in intralamellar tissue adjacent to

M. parakoi Liu, Zhang,

Yang et Zhao, 2019

vessels in gill filaments; SP elongated, pyriform in valvular and sutural Cyprinus carpio Linnaeus;

M. paratoyamai Kato, views, particularly in valvular view, anterior end slightly bent, 15.4 Kasai, Tomochi, Li et Sato, views, particularly in valvular view, anterior end slightly bent, 15.4
2017
$(14.7-16.4) \times 6.3(5.5-6.8) \times 6.1(5.6-6.4)$; only one prominent PC functional, the other rudimentary, $6.5(5.9-7.1) \times 3.7(3.9-4.2), \mathrm{NC}$ 5-6; GBAN: LC228237. Fig. 89.

$\mathrm{P}$ oval, in epithelium of gills filaments; SP asymmetric in frontal view and fusiform in sutural view, $13.8(12.9-14.9) \times 9.9(9.2-11.1) \times 7$;

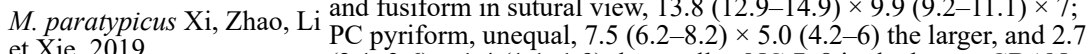
et Xie, 2019 $(2.1-3.6) \times 1.4(1.1-1.9)$ the smaller, $\mathrm{NC} 7-8$ in the larger; GBAN: Irakawa (Kudengawa River, a branch of Fushinogawa River, Yamaguchi City, Japan

\section{Hypophthalmichthys molitrix}

MH119080. Fig. 90.

P ellipsoidal, 0.6-0.8 $\times 0.3-0.4$, around afferent artery of cartilaginous gill arch; SP round or roundish in frontal view, lemonshaped in sutural view, mostly with length somewhat greater than

M. peleci Borzák, Molnár, width, small knob-like structure $0.7(0.6-0.8)$ at anterior end, sutural Pelecus cultratus (Linnaeus);
Cech, Papp, Deák-Paulus et protrusion in frontal view with thick $0.9(0.8-1.9)$ circular rim around Székely, 2016

M. pelecicola Voronin et Dudin, 2015 It is a junior synonym of Myxobolus ladogensis Rumyantsev et Schulman 1997 (Zhang et al. 2019) spore, in sutural view emerging only slightly over surface of spore and
anterior and posterior extremities, $12.1(11.6-13.2) \times 11.4(10.8-12.5)$
$\times 5.8(5.6-6.0)$; PC drop-like, equal, $5.5(5.2-6.0) \times 3.2(2.8-3.4)$, NC 4-5; GBAN: KU170934. Fig. 91.

$\mathrm{P}$ up to 1.2 in length and 0.1-0.4 in width in skeletal muscles; SP

elongate oval, or oval in frontal view, lens-shaped in sutural view, 16.5 Pelecus cultratus (Linnaeus); Voronin and Dudin $(14.9-18.0) \times 12.1(11.6-13.3) \times 7.8(7.4-8.3)$; PC pyriform, unequal in Finnish Bay and Ladoga size, $8.0(7.5-8.5) \times 4.5(4.2-4.7)$ the large, $7.6(7.2-7.8) \times 4.0(3.8-4.3)$ Lake, Russia 
Pyellowish, subspherical to filamentous, attached to visceral

Casal, Alves, Antunes,

P yellowish, subspherical to filamentous, attached to visceral
peritoneum, 1-2 in length; SP oval in valvular view, 8-10 markings near Chelon labrosus (Risso);

peritoneum, 1-2 in length; SP oval in valvular view, 8-10 markings near River Minho (Vila Nova de Rocha et al. (2019b)

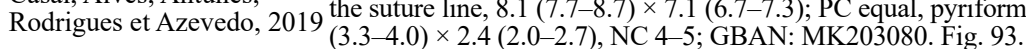

Cerveira), Portugal

$P$ round, creamy white, $2-3$ in diameter, attached to mucous

M. petalum Ghosh et Bandyopadhyay, 2017 membrane of gill lamellae; SP oval in valvular view, shell valve

Labeo rohita (Hamilton);

Ghosh and smooth, 12.0 (11-13) × 5.9 (5-7); PC slender and elongated, equal, 7.9Hooghly River, West Bengal, Bandyopadhyay

$(7-8) \times 2.9(2.5-3)$; filament coils not observed (note: in the camera India lucida drawing of PC filament coils are present). Fig. 94

M. pharyngobranchialis $\quad \mathrm{P}$. in denticular pharyngeal pad of pharyngobranchial organ; SP

Rocha, Casal, Alves,

Antunes, Rodrigues et

Azevedo, 2019

ellipsoidal in valvular and sutural view, 6-8 marking

$9.3(8.7-10.0) \times 7.7(7.0-8.0) \times 5.8(4.7-6.0)$; PC equal, pyriform 4.7 River Minho (Vila Nova de Rocha et al. (2019b) $(4.0-5.3) \times 2.9$ (2.7-3.3), NC 6-7; GBAN: MK203073. Fig. 95 .

$P$ rounded, up to 0.2 in diameter, in pyloric caecum; SP fusiform in

frontal view, $13.0(11.7-13.8) \times 4.3(4.0-4.6) \times 3.8(3.5-4.3)$, with Piaractus brachypomus

M. pirapitingai

Capodifoglio, Adriano,

Naldoni, Meira, Silva et

Maia, 2020

caudal processes longer than spore body, 44.7 (40.5-48.1), giving a (Cuvier); Tapajós River,

SP total length of 57.5 (52.4-61.6); PC elongated, equal, 6.3 (5.6-7.3) Municipality of Santarém,

$\times 1.6(1.3-2.0)$, NC 4; GBAN: MK492647. Fig. 96.

A single big oval and yellowish P, $14 \times 9.3$ free in abdominal cavity in two hosts from Russia, and several small oval and yellowish P, $0.85 \times$ $0.65 \mathrm{~mm}$ embedded in visceral serous membranes in Chinese hosts; SP elongate obovate in frontal view, lemon-shaped in sutural view, 15.1

M. pronini Liu, Batueva, Zhao, Zhang, Zhang, Li et $\mathrm{Li}, 2016$

$(14.3-16.2) \times 10.1(9.6-10.8) \times 6.7(6.4-7.4)$ in Russian isolates, and $14.7(13.8-15.6) \times 9.6(9.0-13.3) \times 6.6(6.2-7.2)$ in Chinese ones; PC Pond near Barguzim Riv
pyriform, equal, $5.4(4.3-6.7) \times 3(4.8-5.6)$ in Russian isolates, and $5.3(4.8-5.6) \times 3.0(2.9-3.4)$ in Chinese isolates, GBAN: KU524889_ Russia KU524890 (SSU), KU524891-KU524892 (LSU) and KU524893-KU 424898 (ITS); note: the Russian locality is considered the typelocality; Chinese material is considered as from other locality. Fig. 97. $P$ round, black or milky white, histozoic in skin; PS pyriform in frontal view and lemon-shaped in lateral view, some spores with caudal appendages $2.2-4.5$ long, $14.6(12.9-16.2) \times 9.4(8.1-10.8) \times 7.0$
$(6.1-8.1) ;$ PC ampullaceous, slighthly unequal in size, $7.9(8.2-9.5)$

M. pseudowulii Zhang, $3.5(3.0-3.9)$ the larger, and $7.4(6.9-8.0) \times 3.4(2.9-3.9)$ the smaller, NC 7-9; GBAN: KY229918. Fig. 98.

$\mathrm{P}$ white, round to irregular, 0.8-1.0 in diameter, in caudal fin; SP ellipsoidal in frontal view and lemon-shaped and lemon-shaped

M. puntiusii Gupta et Kaur, in lateral view, sutural edge markings on posterior end, $7.7 \pm 0.3$ $2017 \times 5.3 \pm 0.15$; PC unequal in size, the larger pyriform, $3.0 \pm 0.1 \times$ $\times 5.3 \pm 0.15 ; \mathrm{PC}$ unequal in size, the larger pyriform, $3.0 \pm 0.1 \times$
$1.8 \pm 0.1, \mathrm{NC} 6-7$, the smaller pyriform or elongated, $1.7 \pm 0.2 \times$ $0.9 \pm 0.1$, NC 3-4; GBAN: KU516662. Fig. 99.

$P$ whitish and filamentous, about $2-3$ in length in gill lamellae; SP M. ramadus Rocha, Casal, spherical to subspherical in valvular view and ellipsoidal in sutural Alves, Antunes, Rodrigues view, $8.2(7.3-9.3) \times 7.9(7.3-8.3) \times 6.4(6.0-6.7)$; PC equal and et Azevedo, 2019 pyriform, $4.2(4.0-4.3) \times 3.0(2.7-2.3)$, NC 5-6; GBAN: MK203 Fig. 100.

$M$ renalis Rocha, Casal, $\mathrm{P}$ in kidney, $\mathrm{SP}$ ellipsoidal to subspherical in valvular view and M. renalis Rocha, Casal, ellipsoidal in sutural view, 8-10 markings near sutural line, 6.7 (6.3$\begin{array}{ll}\text { Alves, Antunes, Rodrigues } & \text { 7.3) } \times 5.8(5.3-6.0) \times 4.6(4.3-5.0) \text {; PC equal, pyriform, 3.1 (2.7-3.7) } \\ \text { et Azevedo, } 2019 & \times 19(2.3-3.0) \text {, NC 4; GBAN: MK203077. Fig } 101\end{array}$ $\times 1.9(2.3-3.0)$, NC 4; GBAN: MK203077. Fig. 101

$\mathrm{P}$ in testicular tissue, looking tumour-like masses, often up to 20 in

M. ridibundae AbdelGhaffar, Abdel-Gaber, diameter, whitish, ovoid or ellipsoidal, $0.3(0.1-0.5)$ in diameter; SP oval in frontal view, biconvex in sutural view, rounded in anterior Maher, El Deeb, Kamel, Al and posterior ends, 2 parietal folds on posterior-lateral margins of Quraishy et Mehlhorn, 2017 shell valves, $9.6(8.9-11.5) \times 8.4(7.5-9.1)$; PC pyriform, equal, 5.2 $(4.3-5.9) \times 3.1(2.2-3.6)$, NC 5-6. Fig. 102 .

$P$ in gill filaments and gill rakers; SP pyriform, rounded in valvular M. saladensis Marcotegui et view and biconvex in sutural view, valves smooth, $10.6(10.0-11.1) \times$
Martoreli, 2017
$9.2(8.4-9.7) \times 4.1(2.6-4.9)$; PC equal, pyriform, $3.8(3.3-4.0) \times 2.3$ (2.1-2.4), NC 4-5. Fig. 103 .

$\mathrm{P}$ white, ovoid or subspherical in heart auricles, $0.14-0.27 \times 0.65-$

0.195; SP ovoid with both rounded ends, 9.9 (9.4-11) $\times 6.8$ (6.1-7.3), Enteromius callipterus

M. sanagaensis Folefack, valves with 5-6 folds at posterior end; PC pyriform, slightly unequal (Boulenger); Lébamzip, Defoueng et Fomena, 2017 in size, $4.6(4.1-5.1) \times 4(3.2-4.3)$, NC 8-10 the larger, 2.3 (2-2.6) $\times$ Sanaga River, Cameroon $2.1(1.8-2.3)$, NC $6-7$ the smaller. Fig. 104.

$\mathrm{P}$ whitish and spherical under skin and in kidney, $0.350 \times 0.345$; SP

M. sessabai Folefack, ovoid with rounded ends, $6-7$ valvular folds at posterior end, 13.4

Defoueng et Fomena, 2017 (12.6-14) × 10.8 (9.9-11.5); PC equal, pyriform, 5.9 (5-6) $\times 3.4$ (2.5-3.8), NC 8-10; well-developed IP, 2.6 (2.1-3.2). Fig. 105

Puntius sophore (Hamilton); Gupta and Kaur Ranjit Sagar Wetland, (2017b)

Chelon ramada (Risso)

River Minho (Vila Nova de Rocha et al. (2019b) Capodifoglio et al. (2020b)

Liu et al. (2016b)

Tachysurus fulvidraco

dson); fish farm in

Zhang et al. (2017)

Punjab, India

Chelon ramada (Risso)

River Minho (Vila Nova de Rocha et al. (2019b) Cerveira), Portugal

Pelophylax ridibundus (Pallas); Kafr El-Sheikh Governorate, Egypt

Abdel-Ghaffar et al. (2017) Mugil liza Valenciennes;
Salado River, Samborombón, Marcotegui and Salado River, Samborombón, Martorelli (2017)

Folefack et al. (2017)

Enteromius callipterus (Boulenger) Lébamzip,

Folefack et al. Sanaga River, Cameroon (2017) $P$ rounded or ellipsoid in gill filaments, usually in middle part of M. sheyangensis Liu, Yuan, filaments; SP flat-pear shaped in frontal view and elongated-shaped M. sheyangensis Liu, Yuan, in sutural view, smooth, some spores with typical Henneguya-like Carassius gibelio (Bloch); Zhao, Fang, Chen et Zhang, in sutural view, smooth, some spores with typical Henneguya-like
2016 PC pyriform, equal, 5.5 (4.5-6.1) × $3.4(2.9-4.0)$, NC 7-8; distinct IP City, East China present; GBAN: KU313484 and KU313485. Fig. 106.

$P$ rounded, 2-3 in diameter, attached to mucous membrane of gill

$M$. sonarpurensis Ghosh et lamellae; SP water droplet shaped in valvular view, surface smooth, Bandyopadhyay, 2017

Ghosh and

Labeo bata (Hamilton); Bandyopadhyay (2017) 
P disseminated throughout cranial nerves and ganglia of head and

M. stellatus Stilwell, Petty, in diameter; SP pyriform, rounded posteriorly and tapering anteriorly, Thoracocharax stellatus M. stellatus Stilwell, Petty, in diameter; SP pyriform, rounded posteriorly and tapering anteriorly, (Kner); Colombia (wild $\begin{array}{ll}\begin{array}{l}\text { Camus, Woodyard, Griffin } \\ \text { et Rosser, } 2020\end{array} & \text { neck-like projection at apical end, unequal, the larger } 9.9(9.1-10.7) \times \text { caught, imported for pet }\end{array}$

$5.4(4.9-6.3)$, NC $8-10$, the smaller $5.0(4.3-5.9) \times 2.6(2.2-3.1)$, NC trade)

Stilwell et al. (2020b)

4-6; IP absent; GBAN: NM795057. Fig. 108.

$\mathrm{P}$ small, round to roundish, $0.06-0.13$ in diameter, in capillary

M. szentendrensis Cech, network of gill lamellae; SP pyriform in frontal view, with well- Chondrostoma nasus

Borzák, Molnár et Székely, defined extrusion at anterior end, 9.2 (8.8-9.6) × 7.9 (7.6-8.0) ×6.7 (Linnaeus); River Danube at Cech et al. (2015) 2015

(6.4-7.1): PC pyriform, equal, 5.3 (4.8-5.6) ×3.0 (2.8-3.2), NC 6; IP Szentendre, Hungary

absent; GBAN: KP025684-KPO25686. Fig. 109.

P ellipsoidal, 1.7-2.9 $\times 0.9-1.7$ in circular muscle layer of inner

M. taibaiensis Liu, Hua, intestinal wall; SP ellipsoidal in frontal view and lemon-shaped in Cyprinus carpio Linnaeus; Zhang, Zhao, Zhang et $\quad$ lateral and apical view, valves smooth, $10.8(10.2-11.2) \times 9.6(9.1-\quad$ Huangmei County, Hubei Zhang, 2017

$9.9) \times 6.3(6.1-6.6)$; PC equal, pyriform, $5.0(4.4-5.4) \times 3.4(3.2-3.6)$, Province, China

NC 4-5; GBAN: KU928249. Fig. 110.

P ellipsoidal, $0.55(0.37-0.82) \times 0.42(0.26-0.63)$, or $0.32(0.20-0.39)$

$\times 0.25(0.15-0.34)$ in intralamellar tissue adjacent to vessels in gill Cyprinus carpio Linnaeus;

M. tanakai Kato, Kasai, filaments; SP elongated, pyriform in valvular and sutural views, 17.2 Kurokawa (Fushinogawa

Tomochi, Li et Sato, $2017 \quad(15.4-16.8) \times 6.8(6.3-8.4) \times 6.3(5.9-6.8)$; PC pyriform, equal in size River), Yamaguchi City, (sometimes unequal), $8.7(7.6-9.4) \times 2.4(2.0-2.7)$, NC 8-10; GBAN: Japan LC 228235 and LC 228236. Fig. 111.

$\mathrm{P}$ whitish, oval and polysporic, up to 5 in diameter, in base of gill M. tapajosi Zatti, Atkinson, filaments; SP smooth, with equal valves, round to oval in frontal Maia, Corrêa, Bartholomew view, biconvex in lateral view, $15(13.5-17) \times 10.7(9.6-11.4)$; et Adriano, 2018 PC elongated, equal, $5(4.6-7.1) \times 3(2.3-3.8)$, NC 6-7; GBAN: MF193890. Fig. 112.

P whitish, ovoid, 1-2 in diameter, in fins, skin and operculum; SP M. tchoumbouei Fonkwa, Tchuinkam, Tomedi et Tchoumboue, 2017 pear-shaped with rounded ends and sometimes flattened anterior end $19.1(17.5-25.5) \times 8.8(7.5-10) ; \mathrm{PC}$ inequal in size, $7.6(6-8.7) \times$ $3(2.5-3.7)$ the larger, $7.0(5.6-8.7) \times 2.6(1.8-4.5)$ the smaller, $\mathrm{NC}$ 7-10. Fig. 113.

Brachyplatystoma rousseauxii (Castelnau); Tapajós River, Santarém, Pará State, Brazil

Enteromius callipterus (Boulanger); Mapé River, Bankim, Adamawa,

Cameroon

In gills (intralamellar vascular type), $\mathrm{P}$ cylindrical to round, white, $0.4-1.5$ in diameter; SP pyriform with elongated anterior end and

M. upmae Gupta et Kaur, 2020

rounded posterior one, valves symmetrical, 9.6 × 5.0; PC subequal and Hypophthalmichthys nobilis pyriform, the larger $4.3 \times 2.3$, the smaller $4.0 \times 2.1$, NC $10-11$ and $8-9$ (Richardson), Ranjit Sagar in the larger and smaller, respectively; IP absent; GBAN: KX757026. Wetland, Punjab, India Fig. 114 .

M. urinaris Rocha, Casal, $\quad \mathrm{P}$ in urinary bladder; SP ellipsoidal in valvular view, 10.0 (9.3-10.3) Mugil cephalus Linnaeus;

Alves, Antunes, Rodrigues $\times 8.2(7.7-8.7)$; PC equal, pyriform, $4.0(3.3-3.7) \times 2.8(2.7-3.0)$; NC River Minho (Vila Nova de et Azevedo, 2019 4-5; GBAN: MK203083. Fig. 115.

Cerveira), Portugal

$P$ in gills, rounded, 0.05 in diameter, or highly elongated, $3.0 \times 0.7$. Cirrhinus mrigala (Hamilton,

$P$ in gills, rounded, 0.05 in diameter, or highly elongated, $3.0 \times 0.7 ; \quad 1822)$, nursery ponds in SP pyriform, with sharply pointed anterior end and rounded posterior 1822), nursery ponds in Ahmad and Kaur one, 10.7 (9.7-11.7) × 4.8 (3.8-5.8); PC equal, elongate, pyriform, 6.5 Village Fagan majra, District ${ }_{(2017)}$ $(5.4-7.5<) \times 1.8(1.1-2.5)$, NC 8-9; IP absent. Fig. 116 . India

$P$ in gall bladder wall; SP ellipsoidal in valvular and sutural view, with , in gall bladder wall; SP ellipsoidal in valvular and sutural view, with Mugil cephalus Linnaeus

Alves, Antunes, Rodrigues et Azevedo, 2019 (2.7-3.7), NC 4-5; GBAN: MK203085. Fig. 117

Cerveira), Portugal

$\mathrm{P}$ in fins, white and spherical, $0.15-0.5$; SP round in frontal view, and Salminus franciscanus

M. vetuschicanus Naldoni, Carriero, Moreira, Silva, Maia et Adriano, 2020

biconvex in lateral view, $10(10.7-11.5) \times(8.1-8.8)$ in frontal view $\mathrm{x} 5.4(5.3-5.5)$ in thickness in lateral view; PC equal, elongated, 4.7 $(4.4-5.3) \times 2.3(1.5-2.7)$, NC 8, GBAN: MT302613. Fig. 118 Flávio, Lima et Britsky; Francisco River, Pirapora, Minas Gerais State, Brazil Liu et al. (2017) $\mathrm{P}$ forming pinkish flower-like aggregates on surface of fins hemisegments, mostly at tips of fins; SP pyriform in frontal view, biconvex in sutural view, pointed anteriorly and rounded posteriorly,

M. xiantaoensis Tahir, Guo, $12.6(11.3-13.9) \times 9.9(8.4-11.1) \times 7.1(6.1-7.7)$; PC unequal and Zhao, Liu et $\mathrm{Gu}, 2019$ eggplant-shaped, the larger $6.8(6.0-8.1) \times 3.4(3.0-3.8)$, the smalle $6.4(5.5-7.4) \times 3.6(3.2-3.9)$, NC 6-8 in both; IP almost $1 / 6$ th of the SP total length; GBAN: KY421105. Fig. 119.

$P$ round and yellowish, about 4-5 in diameter, located bilaterally, dorsal to two opercular openings, with 2 and 3 connected plasmodia M. xinyangensis $\mathrm{Wu}$, Wang, in left and right side of operculum; SP orbicular in frontal view, Sato et Zhang, 2019

$9.4(8.7-10.6) \times 8.6(7.3-9.5) \times 6.4(5.8-7.1)$; PC pyriform, slightly unequal, $5.6(4.3-6.8) \times 3.0(2.4-3.6)$, NC 4-5; GBAN: AF001579. Fig. 120.

$P$ in gills lamellae, creamy white, rounded, 2-3 in diameter; SP tear-

M. zoohuri Majunder Panda, Ghosh et Bandyopadhyay, 2015 shaped, anterior end triangular and posterior one blunt semicircular, $14.8(13.2-17.3) \times 6.3(4.9-7.0)$; PC unequal, the larger 11.1 $\begin{array}{ll}14.8(13.2-17.3) \times 6.3(4.9-7.0) ; \text { PC unequal, the larger 11.1 } & \text { (Hamilton); Canning, South } \\ (10.4-12.0) \times 2.8(2.2-3.1) \text {, NC 17-18, the smaller } 10.6(10.1-11.2) & \text { 24 Parganas, West Bengal } \\ 2.7(2.0-3.0), \text { NC 15-16. Fig. 121. } & \text { India }\end{array}$

Tachysurus fulvidraco

(Richardson); Fish farm in Tahir et al. (2019)

Xiantao, Hubei, China

Gupta and Kaur (2020)

Rocha et al. (2019b)

Rocha et al. (2019b)

Naldoni et al.

Abbottina rivularis

(Basilewsky); Huang River, Wu et al. (2019)

Xinyang City, Henan, China

Cirrhinus mrigala India
(2015) 

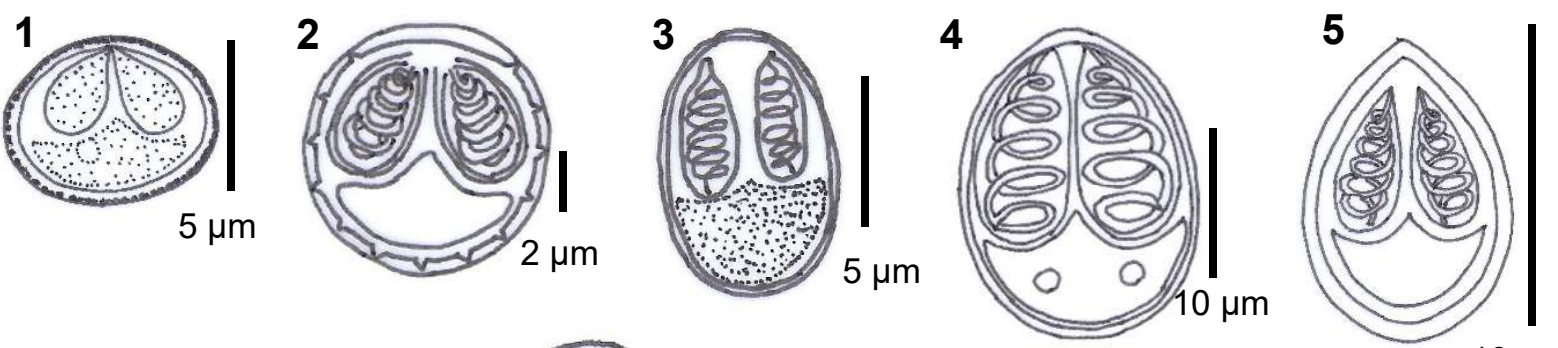

$10 \mu \mathrm{m}$

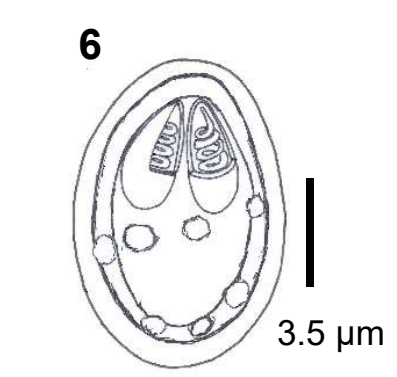

10
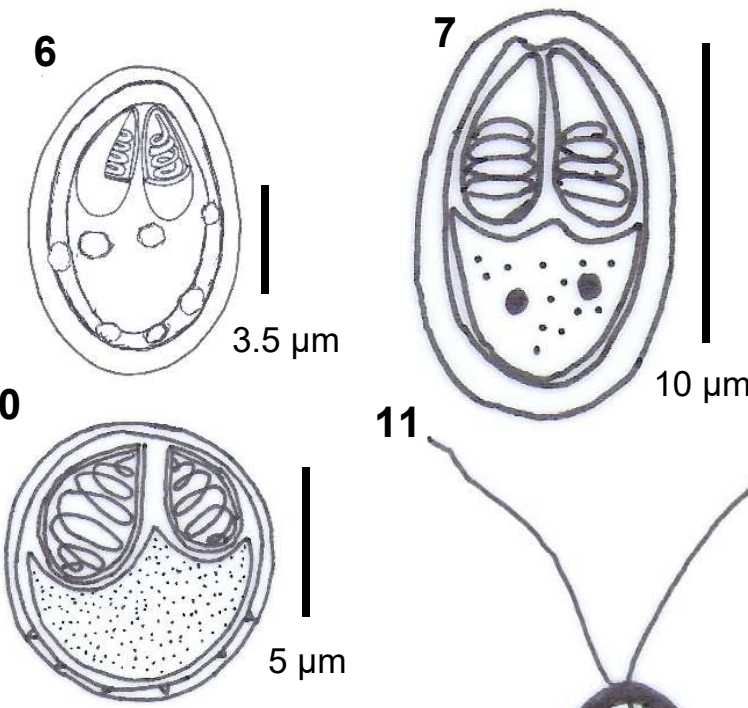

11
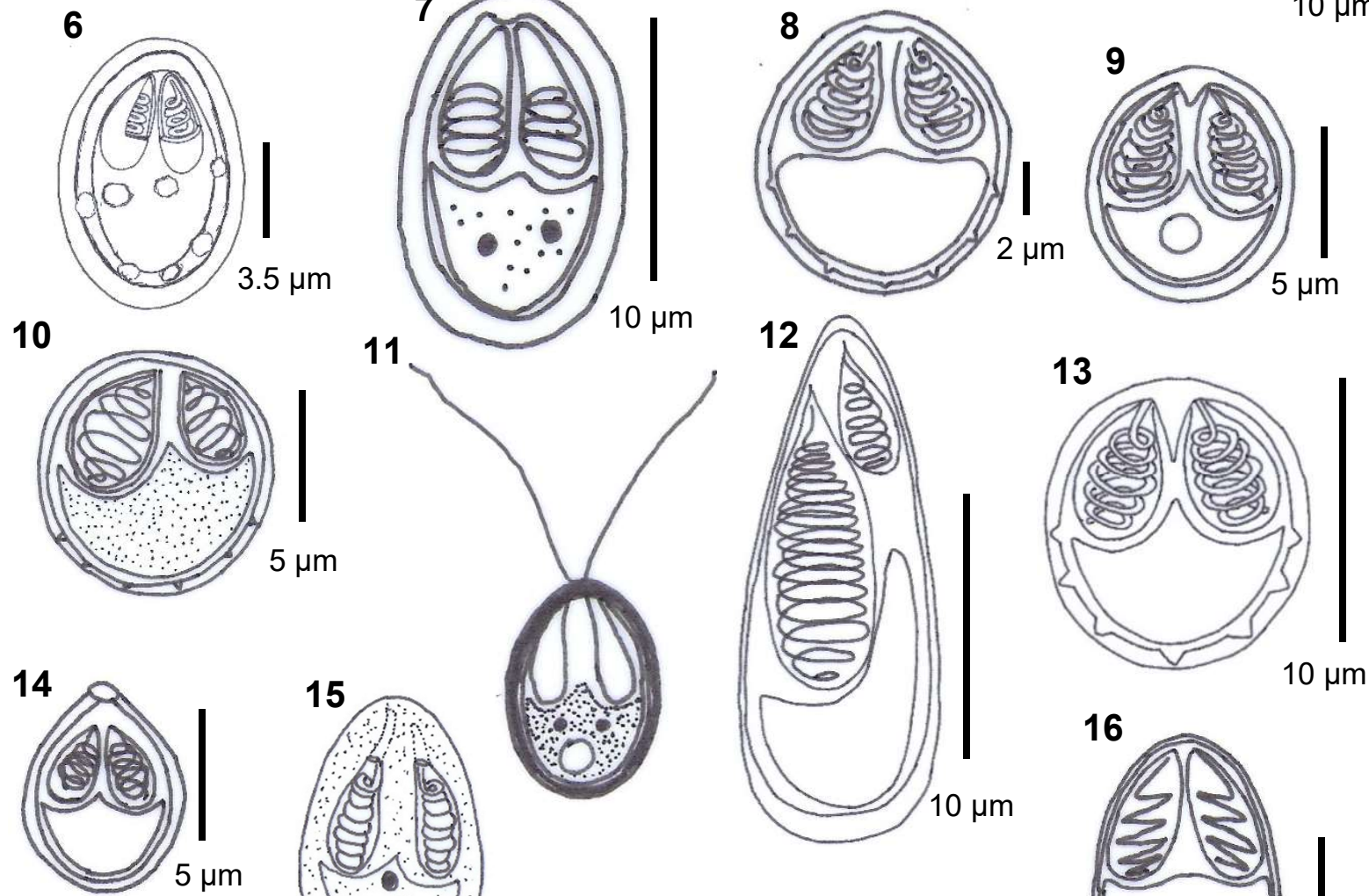

15
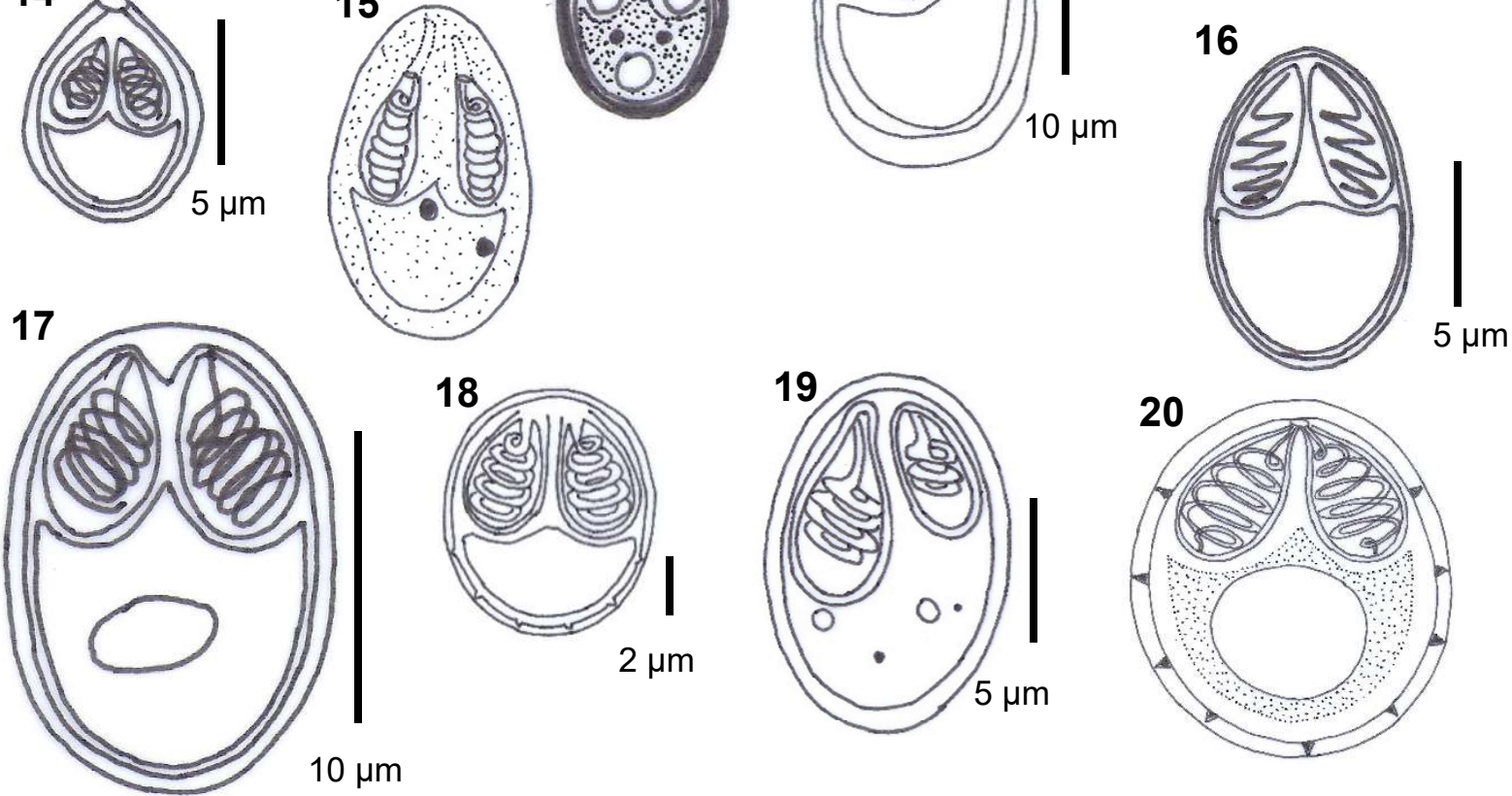

Fig. 1-20. Diagrammatic illustrations of spores of species of Myxobolus Bütschli, 1882. 1 - M. adeli; 2 - M. adiposus; 3 - M. ad-

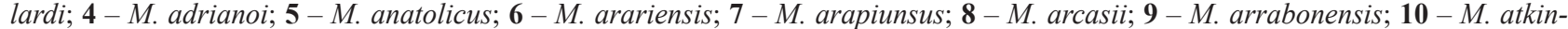
soni; $\mathbf{1 1}$ - M. awadhii (not to scale); $\mathbf{1 2}$ - M. axelrodi; $\mathbf{1 3}-$ M. balatonicus; $\mathbf{1 4}-$ M. basuhaldari; $\mathbf{1 5}-$ M. batalhensis (not to scale); $\mathbf{1 6}$ - M. bejeranoi; $17-$ M. bjoerknae; 18 - M. cerveirensis; $19-$ M. chanosi; 20 - M. chushi (not to scale). Redrawn from the original descriptions (see Table 1 for references). 

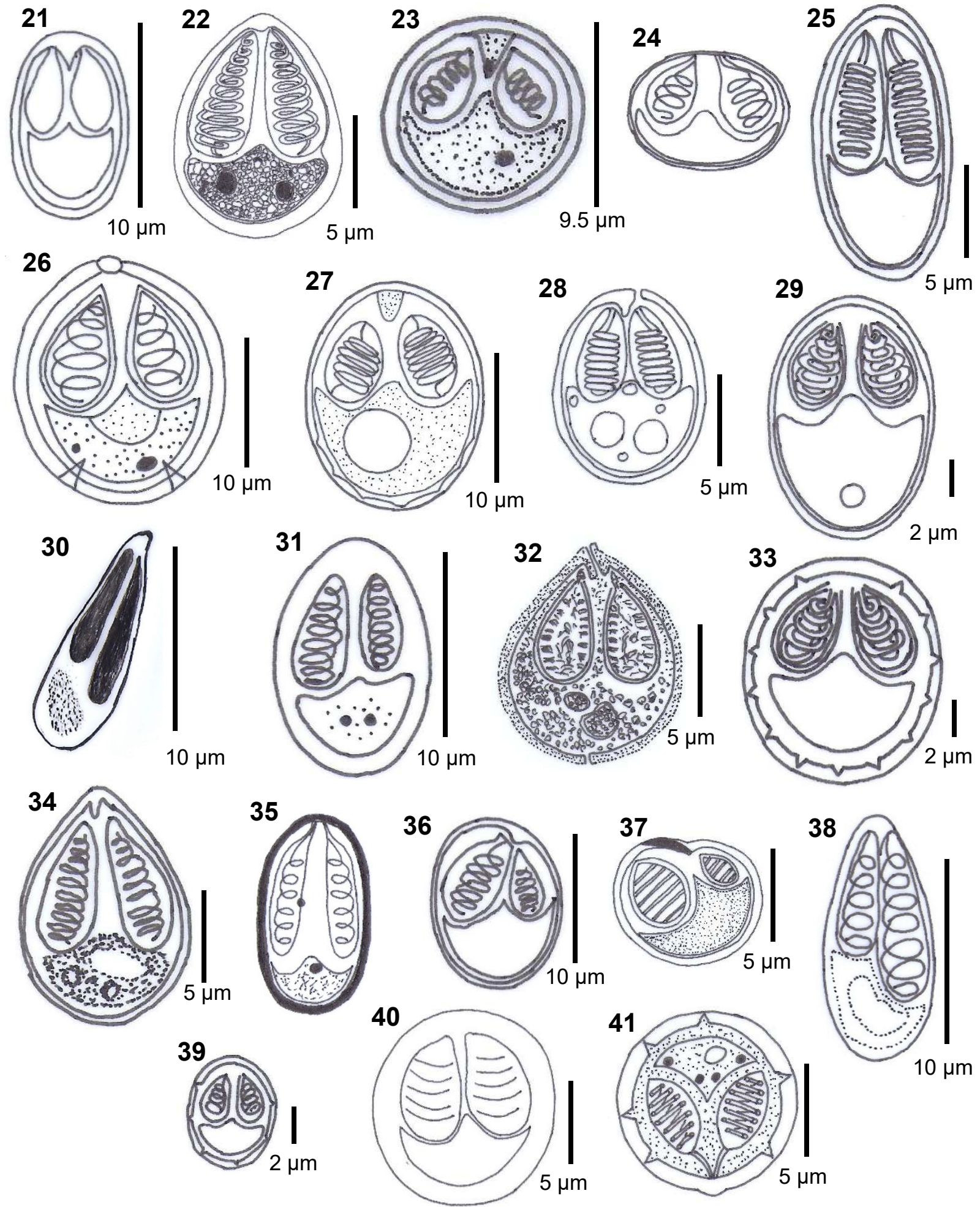

Figs. 21-41. Diagrammatic illustrations of spores of species of Myxobolus Bütschli, 1882. 21 - M. cultrati; 22 - M. curimatae; $\mathbf{2 3}$ - M. danrici; $\mathbf{2 4}$ - M. deformis (not to scale); 25 - M. dermatoulcerans; 26-M. dermiscalis; 27 - M. dibombensis; $28-M$. doubleae; 29 - M. duriensis; 30 - M. elongatum; 31 - M. figueirae; 32 - M. filamentum; 33 - M. galaicoportucalensis; $34-M$. ginbuna; 35 - M. gomtii (not to scale); 36 - M. gutturocola; 37 - M. hardevi; 38 - M. harpreetae; 39 - M. hepatobiliaris; 40 - M. hilarii; 41 - M. himalayaensis. Redrawn from the original descriptions (see Table 1 for references). 

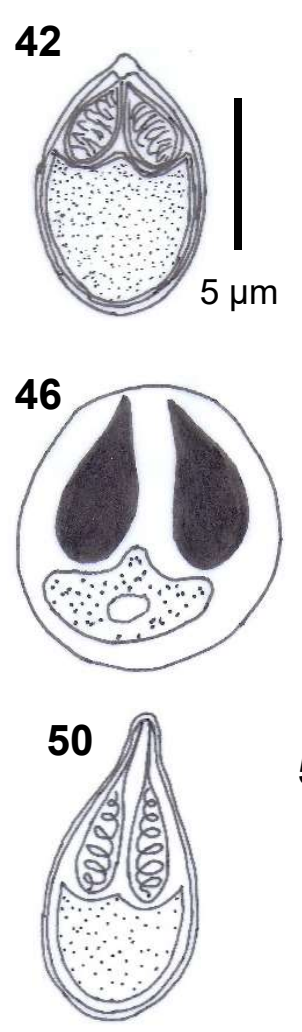

54
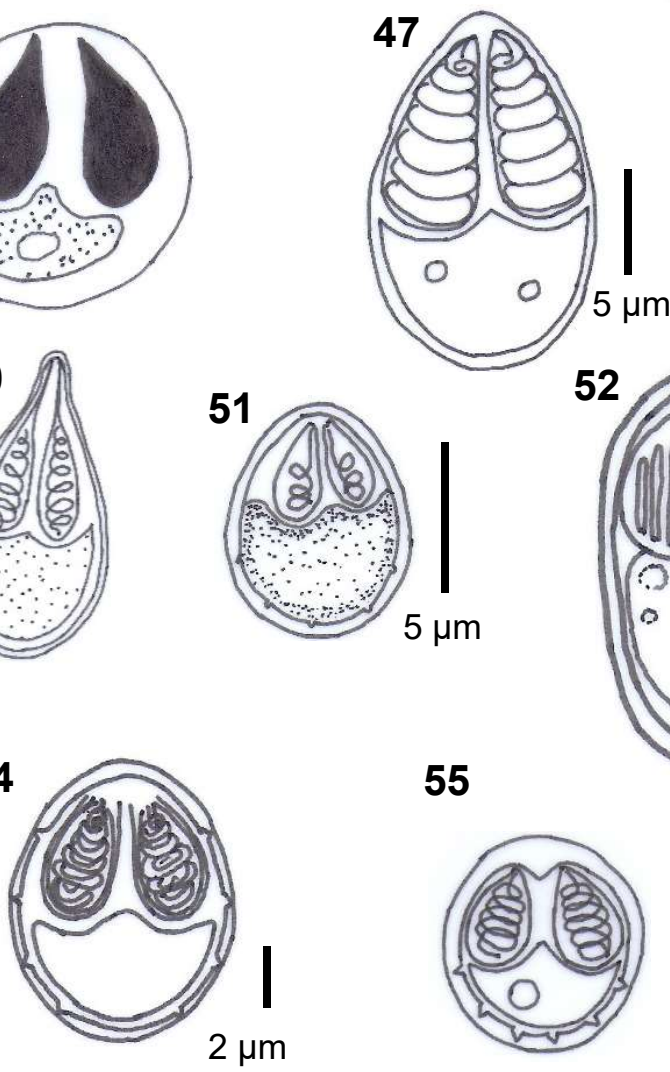

44

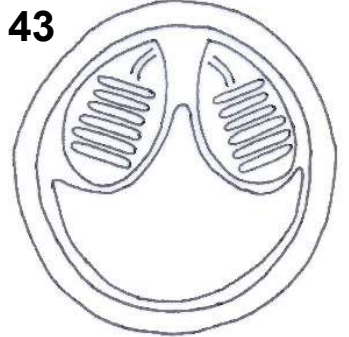

\section{2

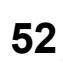

55
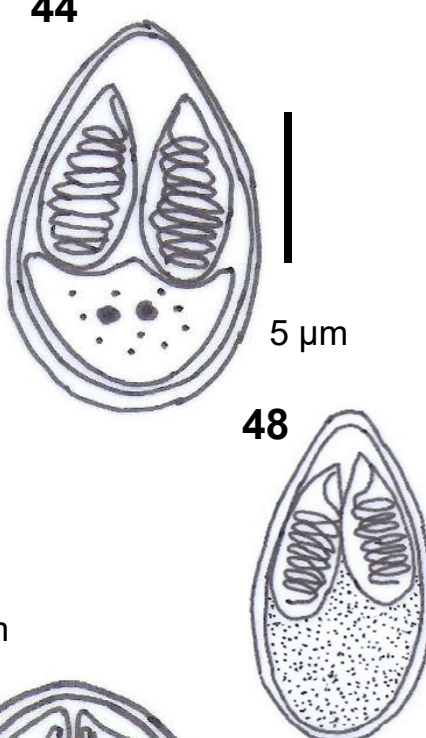

$5 \mu \mathrm{m}$

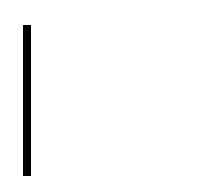

$5 \mu \mathrm{m}$

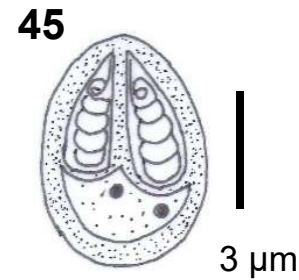

49

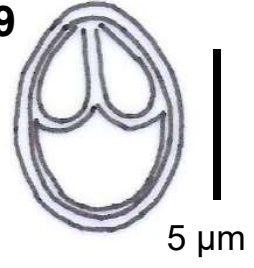

$10 \mu \mathrm{m}$
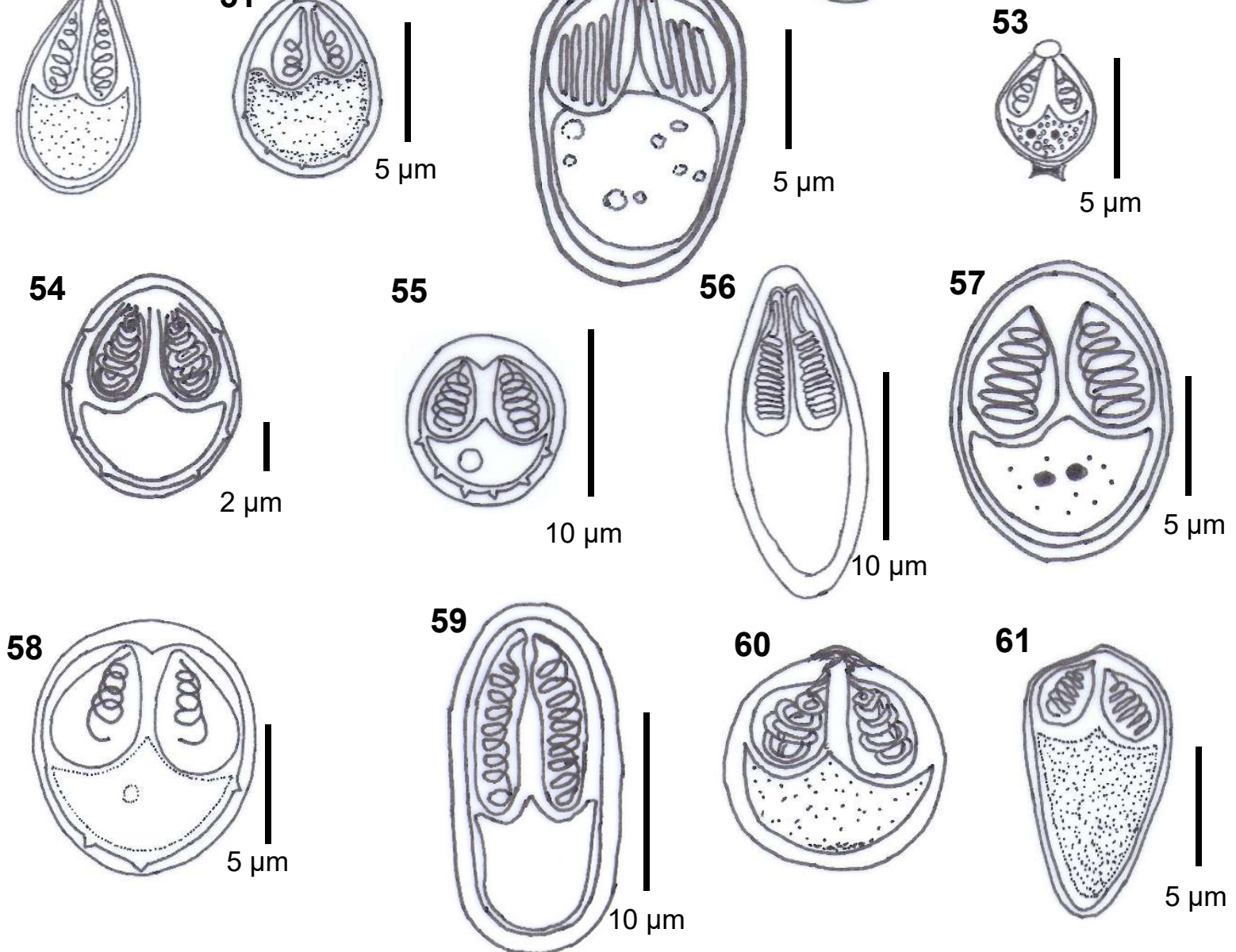

61

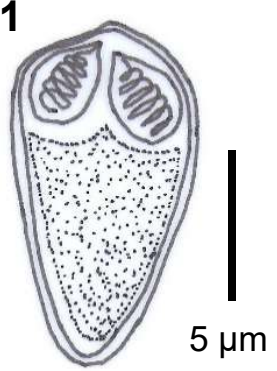

Figs. 42-61. Diagrammatic illustrations of spores of species of Myxobolus Bütschli, 1882. 42 - M. holzerae; 43 - M. ictiobus (not to scale); $44-$ M. iecoris; $\mathbf{4 5}$ - M. imparfinis; $\mathbf{4 6}$ - M. indica (not to scale); 47 - M. iquitoensis; $\mathbf{4 8}$ - M. jialingensis; $\mathbf{4 9}$ - M. kalavatiae; $\mathbf{5 0}$ - M. kashmirensis (not to scale); 51 - M. khaliji; 52 - M. klamathellus; 53 - M. knobii; 54 - M. labrosus; 55 - M. lamellobasis; $\mathbf{5 6}-$ M. lepomis; $57-$ M. lienis; $\mathbf{5 8}-$ M. linzhiensis; $\mathbf{5 9}-$ M. longissimus; $\mathbf{6 0}-$ M. lucknowii (not to scale); $61-M$. magai. Redrawn from the original descriptions (see Table 1 for references). 


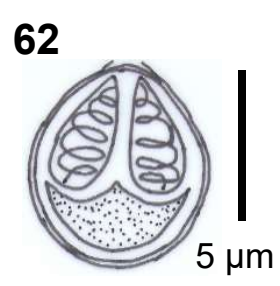

63
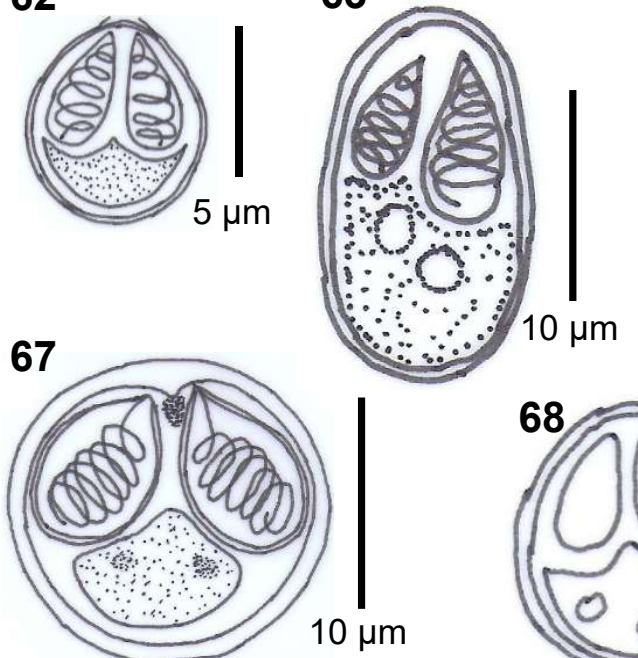

71

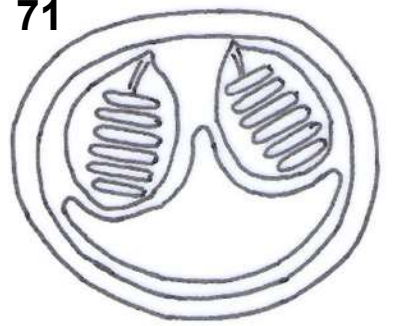

64

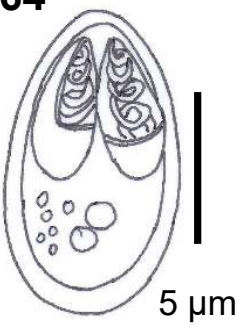

65

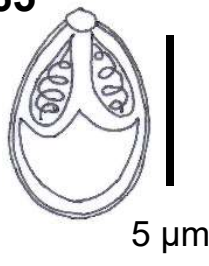

$5 \mu \mathrm{m}$
66
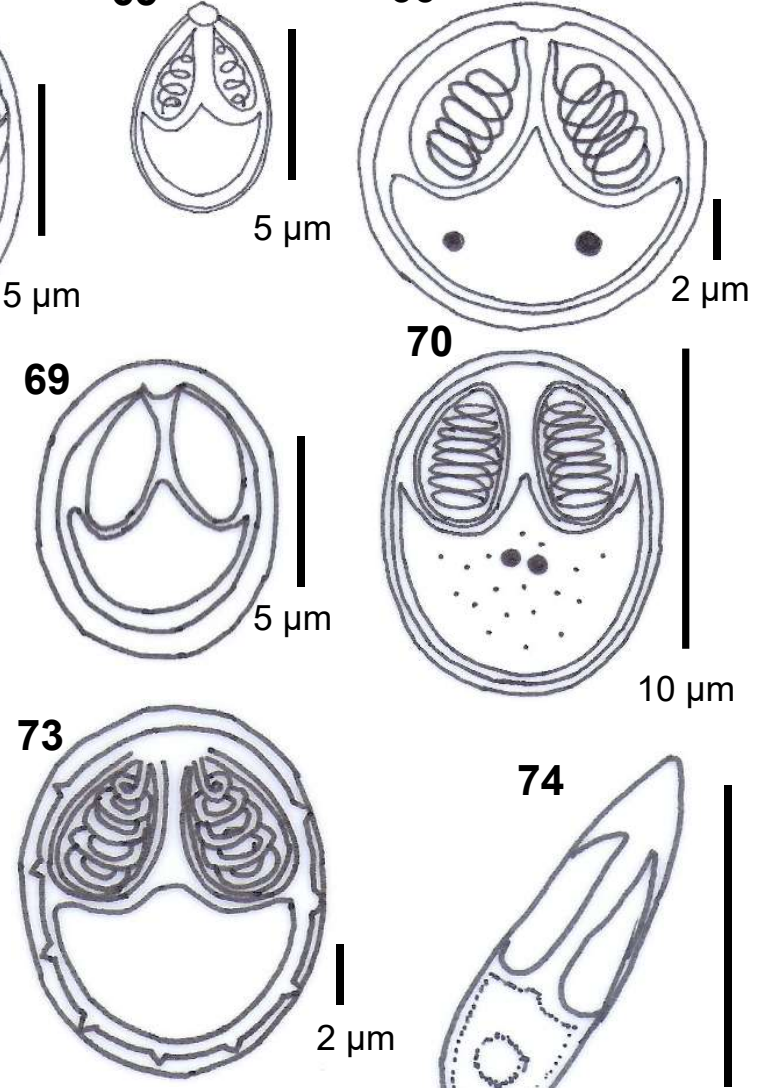

69

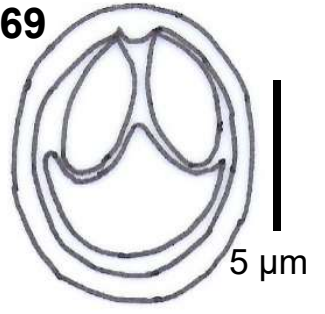

73

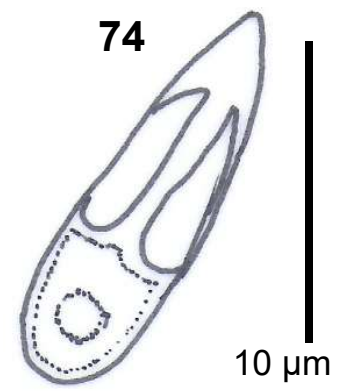

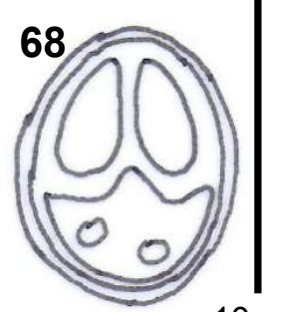

$10 \mu \mathrm{m}$

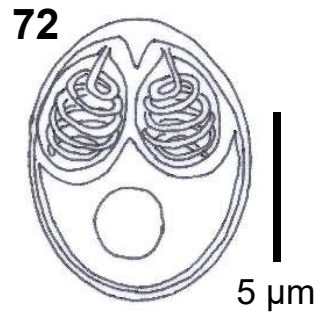

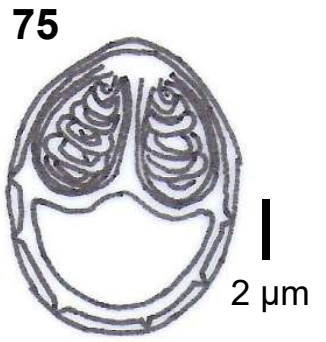
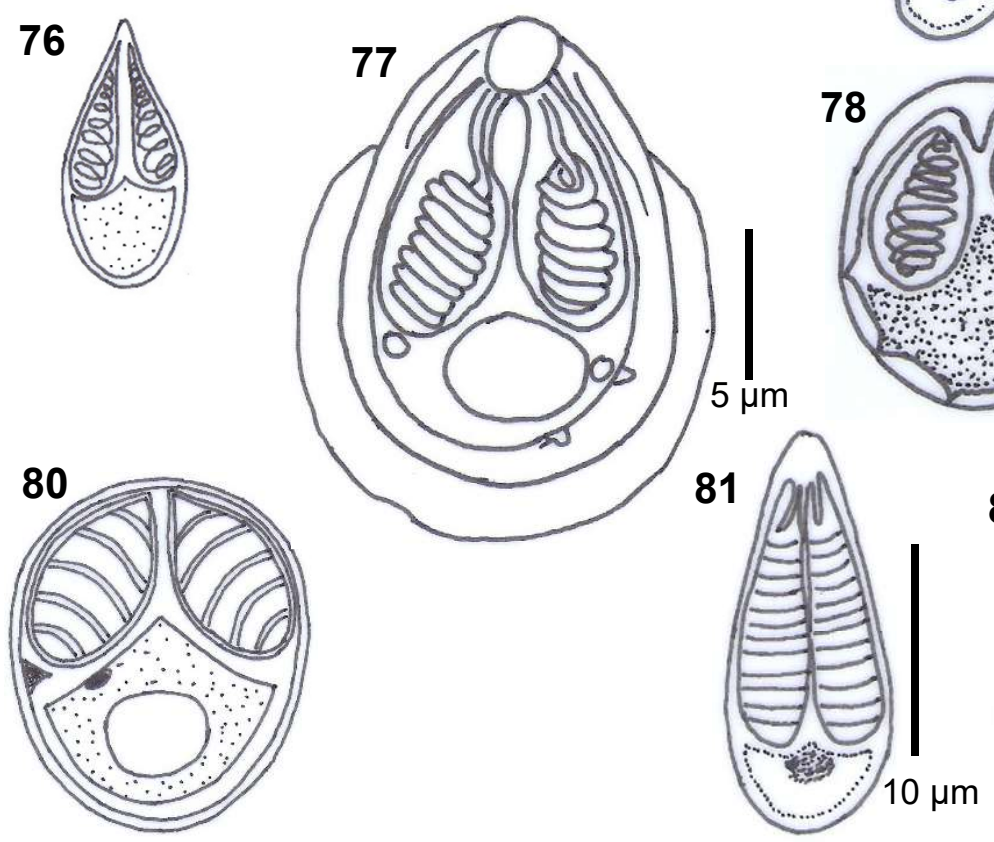

82
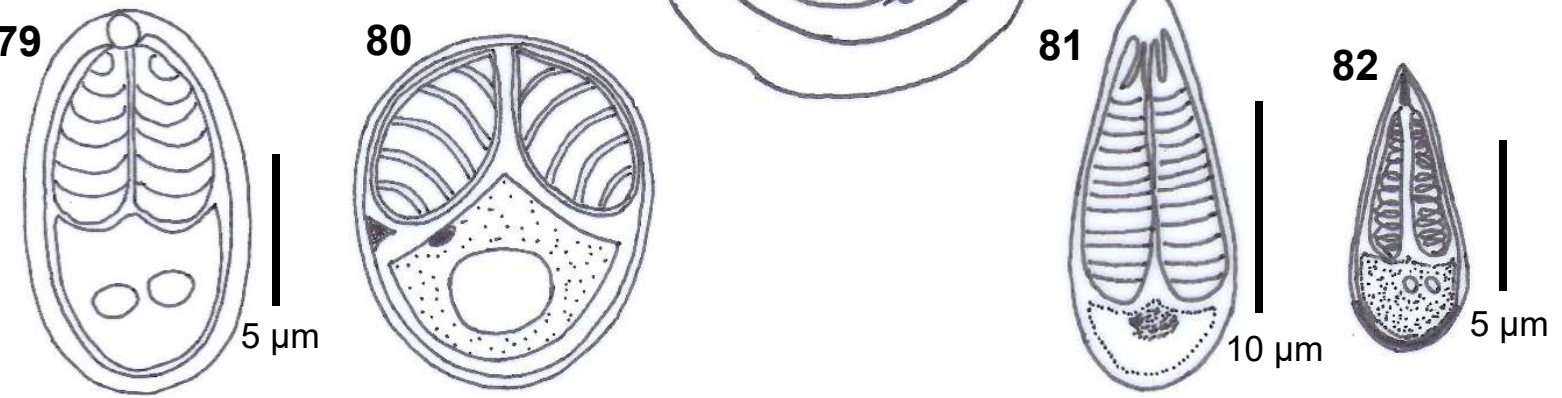

Figs. 62-82. Diagrammatic illustrations of spores of species of Myxobolus Bütschli, 1882. 62 - M. majraiensis; 63 - M. mapei; $\mathbf{6 4}-$ M. marajoensis; $65-$ M. markiwi; 66 - M. mauriensis; $67-$ M. marumotoi; $68-$ M. matosi; $69-$ M. meerutensis; 70 - M. mineirus; $\mathbf{7 1}$ - M. minutus (not to scale); 72 - M. mucosus; $\mathbf{7 3}$ - M. mugiliensis; $74-$ M. muralidharani; $\mathbf{7 5}$ - M. muscularis; 76 - M. nanokiensis (not to scale); $77-M$. neurofontinalis; $78-M$. ngassmi; $79-M$. niger; $\mathbf{8 0}-$ M. nigerai (not to scale); $81-M$. nilimae; $82-M$. okamurae. Redrawn from the original descriptions (see Table 1 for references). 


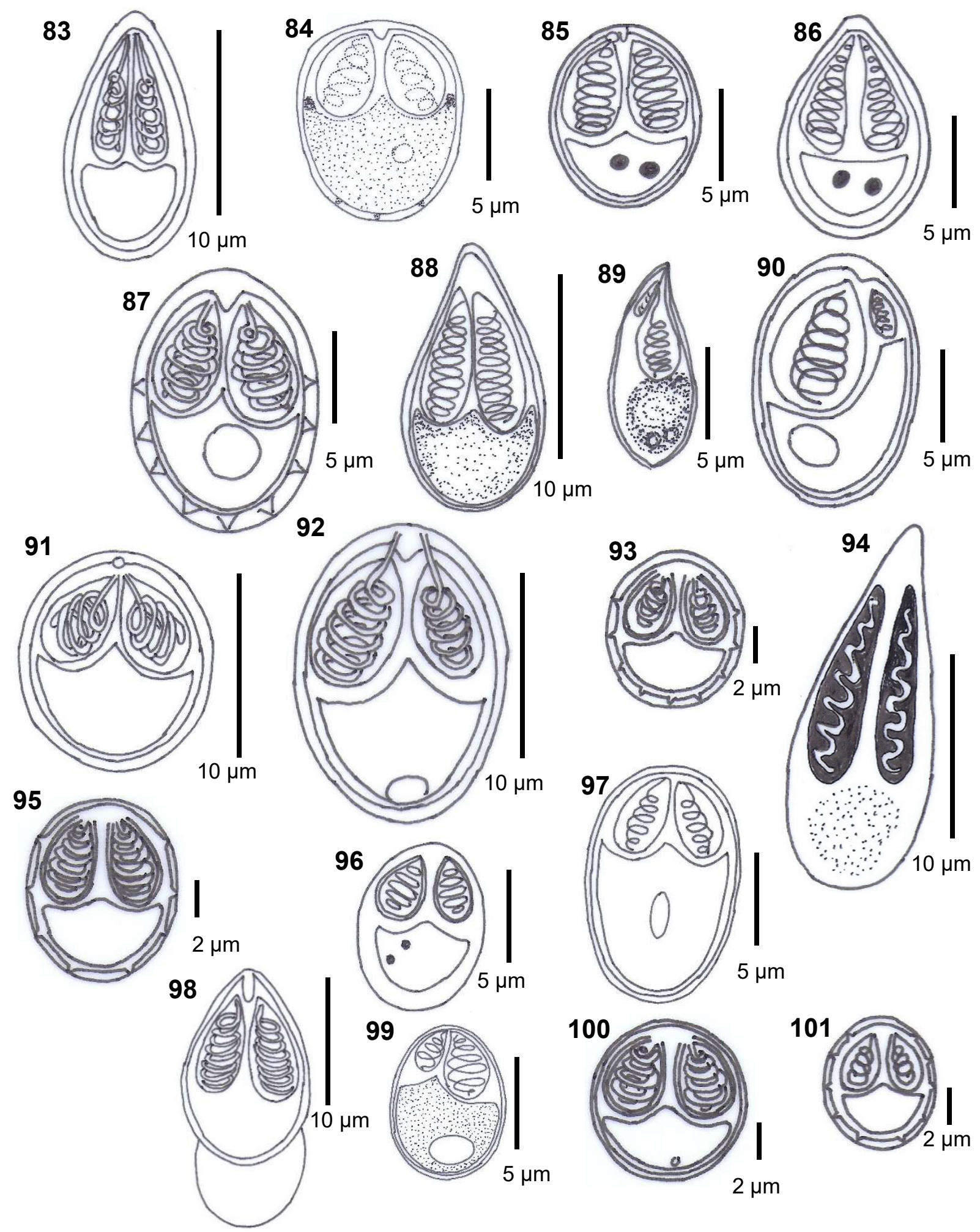

Figs. 83-101. Diagrammatic illustrations of spores of species of Myxobolus Bütschli, 1882. 83 - M. ompok; 84-M. oralis; $85-$ M. or-

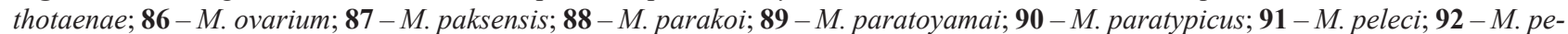
lecicola; 93 - M. peritonaeum; 94 - M. petalum; 95 - M. pharyngobranchialis; 96 - M. pirapitingae; 97 - M. pronini; 98 - M. pseudowulii; 99 - M. puntiusii; 100 - M. ramadus; 101 - M. renalis. Redrawn from the original descriptions (see Table 1 for references). 

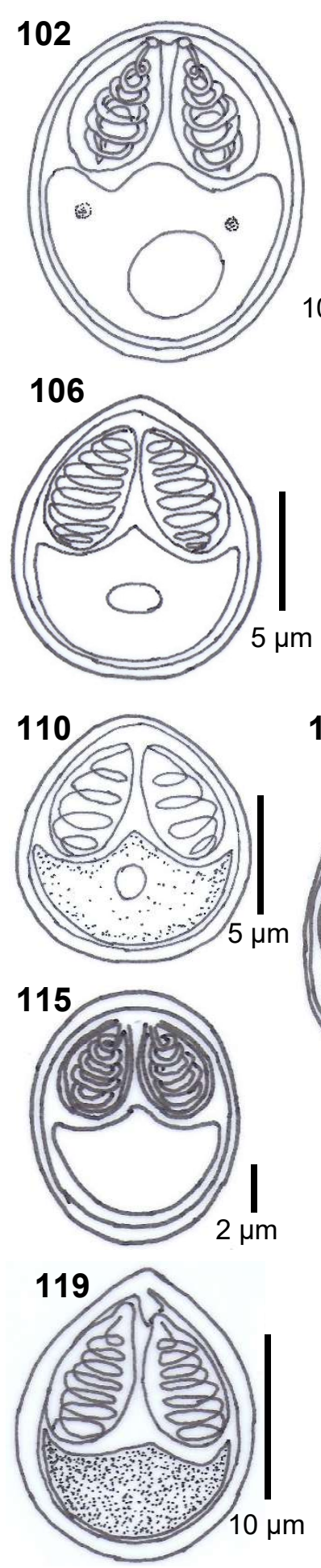
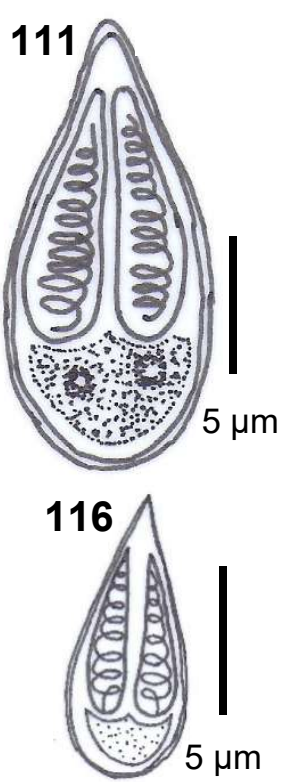

120
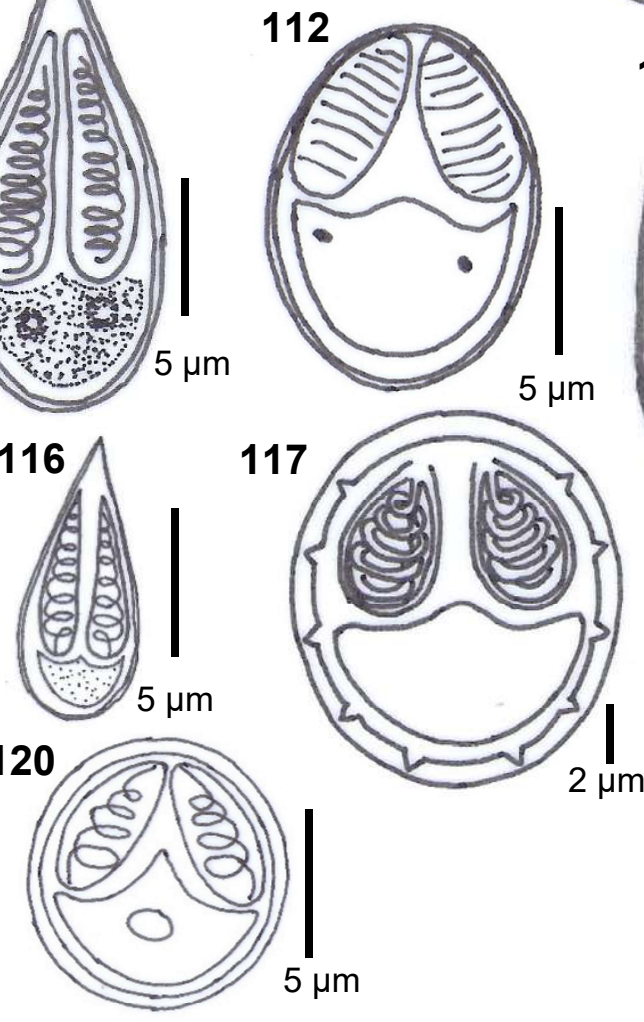

117
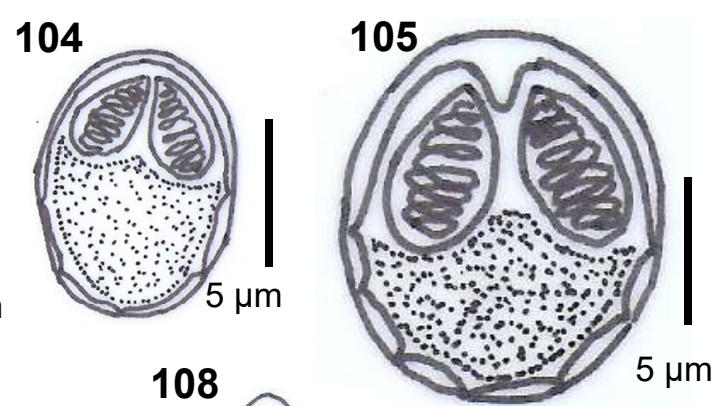

$5 \mu \mathrm{m}$

108
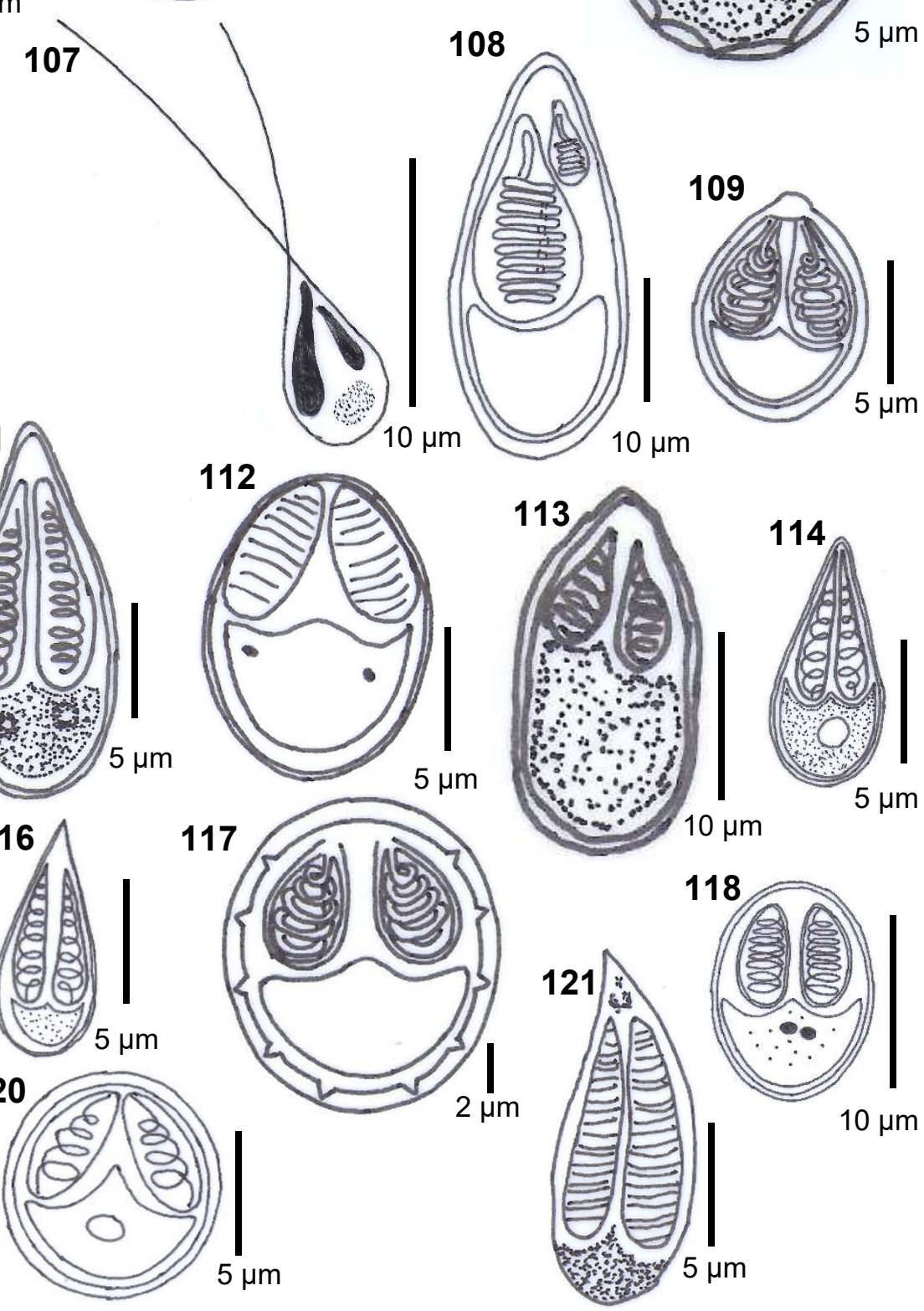

Figs. 102-121. Diagrammatic illustrations of spores of species of Myxobolus Bütschli, 1882. 102 - M. ridibundae; 103 - M. saladensis; 104 - M. sanangaensis; 105 - M. sessabai; 106 - M. sheyangensis; 107 - M. sonarpurensis; 108 - M. stellatus; 109 - M. szentendrensis; 110 - M. taibaiensis; 111 - M. tanakai; 112 - M. tapajosi; 113 - M. tchoumbouei; 114 - M. upmae; 115 - M. urinaris; 116 - M. vascularis; 117 - M. vesicularis; 118 - M. vetuschicanus; 119 - M. xiantaoensis; 120 - M. xinyangensis; 121 - M. zoohuri. Redrawn from the original descriptions (see Table 1 for references). 


\section{REFERENCES}

Abdel-Ghaffar F., Abdel-Gaber R., Maher S., El Deeb N. Kamel R., Al Quraishy S., Mehlhorn H. 2017: Morphological and ultrastructural characteristics of Myxobolus ridibundae n. sp. (Myxosporea: Bivalvulida) infecting the testicular tissue of the marsh frog Rana ridibunda (Amphibia: Ranidae) in Egypt. Parasitol. Res. 116: 133-141.

Abidi R., Fariya N., Chahan U.K. 2016: Morphological description of Myxobolus gomtii sp. nov. infecting Labeo rohita (Hamilton, 1882) from river Gomti at Lucknow in Uttar Pradesh. J. Appl. Biosci. 42: 36-41.

Abidi R., Fariya N., Irshan M., Chauhan U.K. 2015: A new species of myxozoan parasite, Myxobolus lucknowii sp. nov., in kidney of Clarias batrachus Linn. from river Gomti at Lucknow. Trends Parasitol. Res. 4: 5-11.

Abrunhosa J., Sindeaux-Neto J.L., Santos A.K., Hamoy I., Matos E. 2018a: A new species of Myxozoa in the skeletal striated musculature of Rhamdia quelen (Quoy and Gaimard) (Siluriforme: Pimelodidae) Amazonian fish, Marajá Island, Brazil. Zootaxa 4482: 164-176.

Abrunhosa J., Sindeaux-Neto J.L., Santos A.K., Hamoy I., Matos E. 2018b: Myxobolus marajoensis sp. n. (Myxosporea: Myxobolidae), parasita do bagre de água doce Rhamdia quelen da região da Amazônia brasileira. Braz. J. Vet. Parasitol. 26 $465-471$.

Ahmad I., Kaur H. 2017: Myxobolus vascularis n. sp. (Cnidaria: Myxozoa: Myxosporea), a new parasite infecting fingerlings of Indian major carps in aquaculture in Punjab, India. Bull. Pure Appl. Sci. 2: 57-70.

Ahmed I., Ahmad I., Dar S.A., Awas M., Kaur H., Ganai B.A., Sнан B.A. 2019: Myxobolus himalayaensis sp. nov. (Cnidaria: Myxozoa) parasiting Schizothorax richardsonii (Cyprinidae: Schizothoracinae) from River Poonchin, North West Himalaya, India. Aquacul. Reports 14: 100192.

AtKinson S.D., BAnner C.R. 2017: A novel myxosporean parasite Myxobolus klamathellus n. sp. (Cnidaria, Myxosporea) from native blue chub (Gila coerulea) in Klamath Lake, Oregon. Parasitol. Res. 116: 299-302.

Borzák R., Molnár K., Cech G., Papp M., Déak-Paulus P., SzÉKELY C. 2016: Description of two new species of Myxobolus Bütschli, 1892, M. peleci n. sp. and M. cultrati n. sp., detected during an intensive mortality of the sichel, Pelecus cultratus (L.) (Cyprinidae), in Lake Balaton, Hungary. Syst. Parasitol. 93: 667-677.

Camus A.C., Dill J.A., Rosser T.G., Pote L.M., Griffin M.J. 2017: Myxobolus axelrodi n. sp. (Myxosporea: Myxobolidae) a parasite infecting the brain and retinas of the cardinal tetra Paracheirodon axelrodi (Teleostei: Characidae). Parasitol. Res. 116: 387-397.

CAmus A.C., Griffin M. 2010: Molecular Characterization and Histopathology of Myxobolus koi infecting the Gills of a Koi, Cyprinus carpio, with an Amended Morphological Description of the Agent. J. Parasitol. 96(1): 116-124.

Capodifoglio K.R.H., Meira C.M., Silva M.R.M., Corrêa L.L., Adriano E.A., Maia A.A.M. 2020a: Morphology and molecular data of two novel cnidarian myxosporean (Myxobolidae) infecting Piaractus brachypomus from the Amazon basin. Acta Trop. 209: 105533.

Capodifoglio K.R.H., Adriano A.E., Naldoni J., Meira C.M., Silva M.R.M., Maia A.A.M. 2020b: Novel myxosporean species parasitizing an economically important fish from the Amazon basin. Parasitol. Res. 119: 1209-1220.

Capodifoglio K.R.H., Adriano E.A., Silva M.R.M., Maia A.A.M. 2019: The resolution of the taxonomic dilemma of $M y x-$ obolus colossomatis and description of two novel myxosporeans species of Colossoma macropomum from Amazon basin. Acta Trop. 191: 17-23.

Capodifoglio K.R.H., Adriano E.A., Milanin T., Silva M.R.M., Maia A.A.M. 2015: Morphological, ultrastructural and phylogenetic analyses of Myxobolus hilarii n. sp. (Myxozoa, Myxosporea), a renal parasite of farmed Brycon hilarii in Brazil. Parasitol. Int. 65: 184-190.

Cardim J., Silva D., Hamoy I., Matos E., Abrunhosa F. 2018: Myxobolus bragantinus n. sp. (Cnidaria: Myxosporea) from the gill filaments of the redeye mullet, Mugil rubrioculus (Mugiliformes: Mugilidae), on the eastern Amazon coast. Zootaxa 4482: 177-187.

Cech G., Borzák R., Molnár K., Székely C. 2015: Three new species of Myxobolus Bütschli, 1882 (Myxozoa: Myxobolidae) infecting the common nase Chondrostoma nasus (L.) in the River Danube. Syst. Parasitol. 92: 101-111.

Chandran A., Zacharia P.U., Sanil N.K. 2019: Myxobolus chanosi n. sp., a novel myxosporean infecting Chanos chanos (Forsskåll, 1775) from Allapuzha, along the Soutwest coast of India. J. Coastal Res. 86 (Suppl.): 128.

Chaudhary A., Goswami U., Gupta A., Cech G., Singh H.S., Molnár K., Székely C., Shama B. 2018: Morphological, histological and molecular description of Myxobolus ompok n. sp. (Myxosporea: Myxobolidae), a kidney myxozoan from Pabdah catfish Ompok pabda (Hamilton, 1822) (Silurigormes: Siluridae) in India. Parasitol. Res. 117: 1899-1905.

Dar S.A., Kaur H., Chishti M.Z. 2017a: Myxobolus chushi n. sp. (Myxozoa: Myxosporea) parasitizing Schizothorax niger (Heckel), a native cyprinid fish from Wullar Lake in Kashmir Himalayas. Parasitol. Int. 66: 272-278.

Dar S.A., Kaur H., Chishti M.Z. 2017b: First record of myxozoan parasites from fresh water fishes of Jammu and Kashmir and their pathogenicity. Microbial. Pathog. 105: 138-144.

Deli A., Lekeufack F.G.B., Fomena A. 2017: Description of Myxidium tetraodoni, sp. nov, Myxidium anisocapsularis, sp. nov. and Myxobolus magai sp. nov. (Myxosporea: Bivalvulida) infecting some freshwater fishes in Cameroon (Central Africa). Fisheries Aquac. J. 8: 235.

Dar S.A., Kaur H., Chishti M.Z. 2016: Morphological and histopathological description of Myxobolus nigerae $\mathrm{n}$. sp. infecting gills of a cold water native cyprinid fish, Schizothorax niger, from Wullar Lake (India). Species 17: 109-118.

Eiras J.C., Zhang J., Molnár K. 2014: Synopsis of the species of Myxobolus Bütschli, 1882 (Myxozoa, Myxosporea, Myxobolidae) described between 2005 and 2013. Syst. Parasitol. 81: $11-36$

Eiras J.C., Molnár K., Lu Y.S. 2005: Synopsis of the species of the genus Myxobolus Bütschli, 1882 (Myxozoa, Myxosporea, Myxobolidae). Syst. Parasitol. 61: 1-46.

Fariya N., Abidi R., Chauhan U.K. 2018a: Description of new myxozoan parasite Myxobolus awadhii sp. nov from the gills of freshwater catfish Clarias batrachus Linn. J. Parasitic Dis. 42: 598-603.

Fariya N., Abidi R., Chauhan U.K. 2018b: Myxobolus deformis sp. nov. (Myxozoa, Myxosporea, Myxobolidae), a new myxosporean parasite infesting the gills of Cyprinus carpio. Species 19: 4-14.

Folefack G.B.L., Abdel-Baki A.S., Ateba N.O.O., Fomena A., Mansour L. 2019: Morphological and molecular characterization of Myxobolus dibombensis sp. n. (Myxozoa: Myxobolidae), a parasite of the African carp Labeobarbus batesii (Teleostei: Cyprinidae) from Dibombe River, Cameroon. Parasitol. Res. 118: 763-771. 
Folefack G.B.L., Defoueng N.A.S., Fomena A. 2017: Three new species of Myxobolus (Myxosporea: Myxobolidae), parasites of Barbus callipterus Boulenger, 1907 in Cameroon. Asian J. Biol. Sci. 10: 110-120.

Froese R., Pauly D. (Eds.) 2019: FishBase. World Wide Web electronic publication. www.fishbase.org (12/2019).

Gao L., Zhang J., Yang C., Zhao Y. 2020: Myxobolus jialingensis $\mathrm{n}$. sp. (Myxozoa: Myxobolidae) infecting urinary bladder and hepatopancreas of yellow catfish Tachysurus fulvidraco from China. Zootaxa 4819: 179-186.

Georges F., Timoléon T., Minette T.E., Joseph T. 2017: Two new species of Myxobolus (Myxozoa: Myxosporea) parasites of Barbus callipterus Boulenger, 1907 (Cyprinidae) and Oreochromis niloticus Linnaeus, 1758 (Cichlidae) in Cameroon. J. Res. Biol. 7(7): 2355-2360.

Ghosh S., Bandyopadhyay P.K. 2017: Description of three new species of the genus Myxobolus infecting carp fishes of India. J. Parasitic Dis. 41: 155-166.

Ghosh S., Bandyopadhyay P.K. 2016: Morphotaxonomical description of three new species of Myxobolus Bütschli, 1882 (Myxozoa: Myxosporea: Bivalvulida) from edible freshwater fishes of West Bengal, India. J. Parasitic Dis. 41: 97-105.

Gupta A., Kaur H. 2020: Two new species of Myxobolus (Cnidaria: Myxosporea) infecting freshwater fishes of Ranjit Sangar Wetland, Punjab, India. Microbial. Pathog. 147: 104421.

Gupta A., Kaur H. 2018a: 18S and 28S rDNA identity and phylogeny of two novel myxosporeans infecting gills of cyprinid carps inhabiting a coldwater wetland in northern India. Microbial. Pathog. 120: 97-108.

Gupta A., Kaur H. 2018b. Myxobolus okamurae sp. nov. (Myxosporea: Myxozoa) causing severe gill myxoboliosis in the cyprinid Labeo bata in a cold water wetland, Punjab (India). Microbial. Pathog. 115: 86-92.

Gupta A., Kaur H. 2017a: A new pathogen, Myxobolus holzerae (Myxosporea: Myxozoa) causing severe gill disease in an Indian major carp Labeo rohita in a cold-water wetland, Punjab (India). Microbial. Pathog. 111: 244-251.

Gupta A., KaUR H. 2017b: Morphological and molecular characterization of Myxobolus puntiusii n. sp. (Cnidaria: Myxosporea) infecting Puntius sophore Hamilton, 1822 from Ranjit Sagar Wetland, Punjab (India). Turk. J. Zool. 41: 1-9.

Gupta A., Kaur H. 2016: Morphological and histopathological description of Myxobolus adlardi n. sp. (Cnidaria: Myxosporea: Myxozoa) infecting an Indian major carp, Labeo rohita Hamilton, 1822 from a cold-water wetland in Punjab (India). Bull. Pure Appl. Sci. 35: 39-52.

Kato E., Kasai A., Tomochi H., Li Y.C., Sato H. 2017: Four Myxobolus spp. (Myxosporea: Bivalvulida) from the gill lamellae of common carp (Cyprinus carpio) and Japanese silver crucian carp (Carassius langsdorfii) in the western part of Japan, with the description of three new species (M. tanakai n. sp., M. paratoyamai n. sp., and M. ginbuna n. sp.). Parasitol. Res. 116: 2427-2441.

KaUr H., Ahmad I. 2017: A report on two new myxozoan parasites infecting gills of fingerlings of Indian major carps cultured in nursery ponds in Punjab (India). J. Parasitic Dis. 41: 987-996.

Kaur H., Ahmad I. 2016: Morphological description of Myxobolus markiwi n. sp. (Cnidaria: Myxosporea: Myxozoa) infecting gills of fingerlings of aquaculture ponds from Punjab, India. Species 17: 141-149.

Kaur H., Attri R., Joshi J. 2016: Molecular identification of a new myxozoan, Myxobolus dermiscalis n. sp. (Myxosporea) infecting scales of Labeo rohita Hamilton in Harike Wetland, Punjab (India). Int. J. Parasitol. Parasites Wildl. 5: 139-144.

Kaur H., Katoch A., Dar S.A., Singh R. 2015: Myxobolus nanokiensis sp. nov. (Myxozoa: Bivalvulidae), a new pathogenic myxosporean parasite causing haemorrhagic gill disease in cultured Indian major carp fish, Labeo rohita (Hamilton 1822) in Punjab, India. J. Parasitic Dis. 39: 405-4013.
Ksepka S.P., Rash J.M., Whelan N., Bullard S.A. 2019: A new species of Myxobolus (Myxozoa: Bivalvulida) infecting the medulla oblongata and nerve cord of brook trout Salvelinus fontinalis in southern Appalachia (New River, NC, USA). Parasitol. Res. 118: 3241-3252

Li P., Xi B.W., Zhao X., Xie J. 2017: Myxobolus linzhiensis n. sp. (Myxozoa: Myxobolidae) from the gill filament of Schizothorax oconnori Lloyd (Cyprinidae: Schizothoracinae) in Tibet, China: morphological and molecular characterization. Parasitol. Res. 116: 3097-3103

Li Y.C., Sato H. 2014: Two novel myxosporean species (Myxosporea: Bivalvulida), Myxobolus marumotoi n. sp. and Cardimyxobolus japonensis n. sp., from the dark sleeper, Odontobutis obscura, in Japan. Parasitol. Res. 113: 1371-1381.

Liu J.N., Zhang J.Y., Zhao Y.J. 2019a: Morphological and molecular characterization of a new species Myxobolus gutturocola n. sp. (Myxozoa: Myxobolidae) from the throat of Hypophthalmichthys molitrix in China. Parasitol. Res. 118: 733-781.

Liu X.O., Zhang D.D., Yang C.Z., Zhao Y.J. 2019b: Morphological and molecular identification of Myxobolus parakoi sp. nov. (Myxozoa, Myxobolidae) from Cyprinus carpio in Chongquin, China. Zootaxa 4657: 117-126

Liu X., Hua C., Zhang Q., Zhao Y., Zhang D., Zhang J. 2017: Myxobolus taibaiensis sp. n. (Myxozoa: Myxosporea) infecting the intestinal wall of common carp Cyprinus carpio Linnaeus in China. Folia Parasitol. 64: 001

Liu X.H., Voronin V.N., Dudin A.S., Zhang J.Y. 2016a: Morphological and molecular characterization of Myxobolus mucosus sp. n. (Myxosporea: Myxobolidae) with basifilamental sporulation in two cyprinid fishes, Rutilus rutilus (L.) and Leuciscus leuciscus (L.) in Russia. Parasitol. Res. 115: 1297-304.

LiU X.H., Batueva M.D., Zhao Y.L., Zhang J.Y., Zhang Q.Q., Li T.T., Li A.H. 2016b: Morphological and molecular characterisation of Myxobolus pronini n. sp. (Myxozoa: Myxobolidae) from the abdominal cavity and visceral serous membranes of the gibel carp Carassius auratus gibelio (Bloch) in Russia and China. Parasit. Vect. 9: 562.

Liu X.H., Yuan S., Zhao Y.L., Fang P., Chen H., Zhang J.Y. 2016c: Morphological and molecular characterization of Myxobolus sheyangensis $\mathrm{n}$. $\mathrm{sp}$. (Myxosporea: Myxobolidae) with intralamellar sporulation in allogynogenetic gibel carp, Carassius auratus gibelio (Bloch) in China. Parasitol. Res. 115: 3567-74.

LiU Y., Whipps C.M., Nie P., Gu Z. 2014: Myxobolus oralis sp. n. (Myxosporea: Bivalvulida) infecting the palate in the mouth of gibel carp Carassius auratus gibelio (Cypriniformes: Cyprinidae). Folia Parasitol. 61: 505-511.

Lövy A., Smirnov M., Brekhman V., Ofek T., Lotan T. 2018: Morphological and molecular characterization of a novel myxosporean parasite Myxobolus bejeranoi n. sp. (Cnidaria, Myxosporea) from hybrid tilapia in Israel. Parasitol. Res. 117: 491-499.

Lovy J., Hutcheson J.M. 2016: Myxobolus mauriensis n. sp. infecting rib cartilage of young-of-the-year river herring in New Jersey: notes on pathology, prevalence, and genetics. J. Parasitol. 102: 419-428.

Majumder S., Panda S., Ghosh S., Bandyopadhyay P.K. 2015: Description of a new species of Myxobolus Bütschli, 1882 from the Cirrhinus mrigala Hamilton, 1822 an edible fish of India. J. Parasitic Dis. 39: 456-460.

Marcotegui P., Martorelli S. 2017: Myxobolus saladensis sp. nov., a new species of gill parasite of Mugil liza (Osteichthyes, Mugilidae) from Samborombón Bay, Buenos Aires, Argentina. Iheringia, Sér. Zool. 107: e2017026.

Mathews P.D., Madrid R.R.M, Mertins O., Rigoni V.L.S., Morandini A.C. 2020a: A new Myxobolus (Cnidaria: Myxosporea) infecting the ornamental catfish Corydoras schwartzi from the Purus River in Brazil. Eur. J. Taxon. 620: 1-14.

Mathews P.D., Mertins O., Milanin T., Espinoza L.L., Flores-Gonzalez A.P., Audebert F., Morandini A.C. 2020b: Molecular phylogeny and taxonomy of a new Myxobolus species from the endangered ornamental fish, Otocinclus coca- 
$m a$ endemic to Peru: a host-parasite coextinction approach. Acta Trop. 210: 105545.

Mathews P.D., Maia A.A.M., Adriano E.A. 2016: Morphologi$\mathrm{cal}$ and ultrastructural aspects of Myxobolus niger $\mathrm{n}$. sp. (Myxozoa) gill parasite of Corydoras melini (Siluriformes: Callichthyidae) from Brazilian Amazon. Acta Trop. 158: 214-219.

Milanin T., Bartholomew J.L., Atkinson A.D. 2020: Myxobolus spp. (Cnidaria: Myxozoa) in introduced yellow perch Perca flavescens (Mitchill, 1814). Parasitol. Res. 119: 893-901.

Mohilal N., Sony T. 2017: Myxobolus danrici sp. n. (Cnidaria Myxosporea, Myxobolidae), a myxozoan parasite of Esomus danrica Hamilton, 1882 from ponds and ditches of Thoubal, Manipur, India. Bull. Pure Appl. Sci.-Zool. 36: 93-101.

Molnár K., Székely C., Guti C.F., Eszterbauer E. 2014: Two new Myxobolus spp. (Myxozoa: Myxobolidae) from white bream, Blicca bjoerkna (Linnaeus, 1758) developing in basifilamental location of gills. Acta Protozool. 53: 277-285.

Naldoni J., Carriero M.M., Moreira G.S.A., Silva M.R.M., Maia A.A.M., Adriano E.A. 2020a: Increasing the known biodiversity of cnidarian parasites of bryconid fishes from South America: two novel Myxobolus species with ultrastructure and ssrDNA - based phylogeny. Parasitol. Res. 19: 3627-3637.

Naldoni J., Pereira J.O.L., Milanin T., Adriano E.A., Silva M, R, M., Maia A. A.M. 2020b: Taxonomy, phylogeny and host-parasite interaction of two novel Myxobolus species infecting Brycon orthotaenia from the São Francisco River, Brazil. Parasitol. Int. 76: 102061.

Naldoni J., Zatti S.A., Silva M.R.M., Maia A.A., Adriano E.A. 2019: Morphological, ultrastructural, and phylogenetic analysis of two novel Myxobolus species (Cnidaria: Myxosporea) parasitizing bryconid fish from São Francisco River, Brazil. Parasitol. Int. 71: 27-36.

Naldoni J., Maia A.A.M., Correa L.L., Silva M.R.M., AdriANO E.A. 2018: New myxosporeans parasitizing Phractocephalus hemioliopterus from Brazil: morphology, ultrastructure and SSU-rDNA sequencing. Dis. Aquat. Org. 128: 37-49.

Naldoni J., Zatti S.A., Capodifoglio K.R.H., Milanin T., Maia A.A., Silva M.R., Adriano E.A. 2015: Host-parasite and phylogenetic relationships of Myxobolus filamentum sp. n. (Myxozoa: Myxosporea), a parasite of Brycon orthotaenia (Characiformes: Bryconidae) in Brazil. Folia Parasitol. 62: 014.

Pekmezci G.Z., Yardimci B., Yilmaz S., Polat N. 2014: Myxobolus anatolicus sp. nov. (Myxozoa) infecting the gill of Anatolian khramulya Capoeta tinca (Cyprinidae) in Turkey. Dis. Aquat. Org. 109: 213-222.

Rocha S., Azevedo C., Alves Â., Antunes C., Casal G. 2019a: Morphological and molecular characterization of myxobolids (Cnidaria, Myxozoa) infecting cypriniforms (Actinopterygii, Teleostei) endemic to the Iberian Peninsula. Parasite 26: 48.

Rocha S., Casal G., Alves A., Antunes C., Rodrigues G., Azevedo C. 2019b: Myxozoan biodiversity in mullets (Teleostei, Mugilidae) unravels hyperdiversification of Myxobolus (Cnidaria, Myxosporea). Parasitol. Res. 118: 3279-3305.

Rosser T.G., Baumgartner W.A., Barger M.A., Griffin M.J. 2017: Myxobolus lepomis n. sp. (Cnidaria: Myxobolidae), a gill myxozoan infecting Lepomis marginatus Holbrook and Lepomis miniatus Jordan (Perciformes: Centrarchidae), in the Big Thicket National Preserve, Texas, USA. Syst. Parasitol. 94: 535-545.

Rosser T.G., Griffin M.J., Quiniou S.M.A., Alberson N.R., Woodyard E.T., Mischke C.C., Greenway T.E., Wise D.J., Pote L.M. 2016: Myxobolus ictiobus n. sp. and Myxobolus minutus n. sp. (Cnidaria: Myxobolidae) from the gills of the smallmouth buffalo Ictiobus bubalus Rafinesque (Cypriniformes: Catostomidae). Syst. Parasitol. 93: 565-574.

Saha M., Bandyopadhyay P.K. 2017: Light and scanning electron microscopic studies of Myxobolus indica $\mathrm{n}$. sp. and a report of three Myxozoan (Myxosporea: Bivalvulida) parasites of cultured ornamental goldfish, Carassius auratus $\mathrm{L}$. for the first time in India. Aquacul. Rep. 7: 66-76.
Stilwell J.M., Stilwell N.K., Camus A.C., Ware C., Rosser T.G., GRIFFIN M.J. 2020a: Necroulcerative dermatitis associated with Myxobolus dermatoulcerans n. sp. (Cnidaria: Myxobolidae) in redbellied piranha, Pygocentrus nattereri Kner (Characiformes: Serrasalmidae), from Peru. Syst Parasitol, 7: 649-659.

Stilwell J.M., Petty, B.D. Camus A.C., Woodyard, E.T., Griffin, M.T., Rosser, T.G. 2020b: Characterisation of Myxobolus stellatus $\mathrm{n}$. sp. (Cnidaria: Myxobolidae) infecting the cranial nerves and ganglia of the spotfin hatchetfish Thoracocharax stellatus (Kner) (Characiformes: Gasteropelecidae) from Colombia. Syst. Parasitol. 97: 305-314.

Székely C., Molnár K., Cech G. 2015a: Description of Myxobolus balatonicus n. sp. (Myxozoa: Myxobolidae) from the common carp Cyprinus carpio L. in Lake Balaton Syst. Parasitol. 91: 71-79.

Székely C., Cech G., Chaudhary A., Borzk R., Singh H.S., Molnár K. 2015b: Myxozoan infections of the three Indian major carps in fish ponds around Meerut, UP, India, with descriptions of three new species, Myxobolus basuhaldari sp. n., M. kalavatiae sp. n. and M. meerutensis sp. n., and the redescription of M. catlae and M. bhadrensis. Parasitol. Res. 114: 1301-1311.

Tahir U.B., Guo Q.X., Zhao D.D., Liu Y., Gu Z. 2019: Description of Myxobolus xiantaoensis n. sp. from the fins of yellow catfish in China: a species previously attributed to Myxobolus physophilus Reuss, 1906 in Chinese records. Parasitol. Res. 118: 1137-1143.

Vieira D.H.M.D., Tagliavini V.P., Abdallah V.D., AzeveDo R.K. 2018: Myxobolus imparfinis n. sp. (Myxozoa: Myxosporea), a new gill parasite of Imparfinis mirini Haseman (Siluriformes: Heptapteridae) in Brazil. Syst. Parasitol. 95: 309-318.

Vieira D.H.M.D., Alama-Bermejo G., Bartholomew J.L., Abdallah V.D., Azevedo R.K. 2017: Morphological and molecular description of Myxobolus batalhensis n. sp. (Myxozoa, Myxosporea), a liver and ovary parasite of Salminus hilarii in Brazil. Parasitol. Res. 116: 3303-3313.

Voronin V.N., Duduin A.S., 2015: [The description of Myxobolus pelecicola sp. nov. (Myxozoa: Myxobolidae) from Pelecus cultratus (Cypriniformes, Cyprinidae)]. Parazitologiya 49: 257-263. (In Russian.)

Wu W., Wang Q.S., Sato H., Zhang J.Y. 2019: Morphological and molecular characterization of muscle-infecting myxosporean Myxobolus xinyangensis sp. nov. from Abbottina rivularis in China. Dis. Aquat. Org. 132: 171-179.

Xi B.W., Zhao X., Li P., XIE J. 2019: Morphological variation in Myxobolus drjagini (Akhmerov, 1954) from silver carp and description of Myxobolus paratypicus n. sp. (Cnidaria: Myxozoa). Parasitol. Res. 118: 2149-2157.

Yurakhno V.M., Ovcharenko M.O. 2014: Study of Myxosporea (Myxozoa), infecting worldwide mullet with description of a new species. Parasitol. Res. 113: 3661-3674.

Zatti S.A., Atkinson S.D., Maia A.A.M., Corrêa L.L., Bartholomew J.L. Adriano E.A. 2018: Novel Myxobolus and Ellipsomyxa species (Cnidaria: Myxozoa) parasitising Brachyplatystoma rousseauxii (Siluriformes: Pimelodidae) in the Amazon basin, Brazil. Parasitol. Int. 67: 612-621.

Zatti S.A., Naldoni J., Silva M.R.M., Maia A.A.M., AdriANO E.A. 2015: Morphology, ultrastructure and phylogeny of Myxobolus curimatae n. sp. (Myxozoa: Myxosporea) a parasite of Prochilodus costatus (Teleostei: Prochilodontidae) from the São Francisco River, Brazil. Parasitol. Int. 64: 362-368.

Zhang J.Y., Liu X.H., Voronin V.N., Dudin A.S., ToKarev Y.S. 2019: Myxobolus pelecicola Voronin et Dudin 2015 is a junior synonym of Myxobolus ladogensis Rumyantsev et Schulman 1997 (Myxosporea: Myxobolidae) infecting the skeletal muscle of sichel Pelecus cultratus (Actinopterygii: Cyprinidae) in Russia. Parasitol. Res. 118: 3099-3103.

Zhang B., Zhai Y., Liu Y., Gu Z. 2017: Myxobolus pseudowulii sp. n. (Myxozoa: Myxosporea), a new skin parasite of yellow catfish Tachysurus fulvidraco (Richardson) and redescription of Myxobolus voremkhai (Akhmerov, 1960). Folia Parasitol. 64: 030. 
Zhang J.Y., Al-Quraishy S., AbDel-Azeem S., AbDel-BaKi

A.A. 2014: The morphological and molecular characterization of Myxobolus khaliji n. sp. (Myxozoa: Myxosporea) from the double bar seabream Acanthopagrus bifasciatus (Forsskål, 1775) in the Arabian Gulf, Saudi Arabia. Parasitol. Res. 113: 2177-2183.

Cite this article as: Eiras J.C., Cruz C.F., Saraiva A., Adriano E.A. 2021: Synopsis of the species of Myxobolus (Cnidaria, Myxozoa, Myxosporea) described between 2014 and 2020. Folia Parasitol. 68: 012. 